\begin{tabular}{|l||}
\hline Athens Journal of Philology \\
Volume 6, ISSue 4, December 2019 \\
Articles \\
Front Pages \\
VICTOR GINSBURGH \& STAMOS METZIDAKIS \\
On Rimbaud's "Vowels," Again: Vowels or Colors? \\
ALEXANDRA REUBER \\
The (Silent) Articulation of Otherness: Maurice Blanchot's Double Parole \\
in Death Sentence, Awaiting Oblivion, and Madness of the Day \\
RAMIN FARHADI \& MOHAMMAD AMIN MOZAHEB \\
Power and Resistance: Disappointment of Socialism in Howard \\
Brenton's Magnificence \\
Metaphorical Euphemisms in the Original Text and Italian Translations \\
of F.M. Dostoevskii's Novel Crime and Punishment \\
\hline
\end{tabular}




\section{Mission}

ATINER is a World Non-Profit Association of Academics and Researchers based in Athens. ATINER is an independent Association with a Mission to become a forum where Academics and Researchers from all over the world can meet in Athens, exchange ideas on their research and discuss future developments in their disciplines, as well as engage with professionals from other fields. Athens was chosen because of its long history of academic gatherings, which go back thousands of years to Plato's Academy and Aristotle's Lyceum. Both these historic places are within walking distance from ATINER's downtown offices. Since antiquity, Athens was an open city. In the words of Pericles, Athens "...is open to the world, we never expel a foreigner from learning or seeing" ("Pericles' Funeral Oration", in Thucydides, The History of the Peloponnesian War). It is ATINER's mission to revive the glory of Ancient Athens by inviting the World Academic Community to the city, to learn from each other in an environment of freedom and respect for other people's opinions and beliefs. After all, the free expression of one's opinion formed the basis for the development of democracy, and Athens was its cradle. As it turned out, the Golden Age of Athens was in fact, the Golden Age of the Western Civilization. Education and (Re)searching for the "truth" are the pillars of any free (democratic) society. This is the reason why Education and Research are the two core words in ATINER's name. 
Athens Journal of Philology

ISSN NUMBER: 2241-8385

DOI: $10.30958 / a j p$

Volume 6, Issue 4, December 2019

Download the entire issue (PDF)

Front Pages

On Rimbaud's "Vowels," Again: Vowels or Colors?

Victor Ginsburgh \& Stamos Metzidakis

The (Silent) Articulation of Otherness: Maurice Blanchot's

Double Parole in Death Sentence, Awaiting Oblivion, and

Madness of the Day

Alexandra Reuber

Metaphorical Euphemisms in the Original Text and Italian

Translations of F.M. Dostoevskii's Novel Crime and

Punishment

Aleksandra Burkhailo

Power and Resistance: Disappointment of Socialism in

Howard Brenton's Magnificence

Ramin Farhadi \& Mohammad Amin Mozaheb 


\section{Athens Journal of Philology Editorial and Reviewers' Board}

\section{Editors}

- Dr. Stamos Metzidakis, Head, Literature Research Unit \& Emeritus Professor of French and Comparative Literature, Washington University in Saint Louis, USA.

- Dr. Giorgio Graffi, Academic Member, ATINER \& Professor Emeritus, University of Verona, Italy.

\section{Editorial Board}

- Dr. Nicholas Pappas, Vice President of Academic Membership, ATINER \& Professor of History, Sam Houston University, USA.

- Dr. David Philip Wick, Director, Arts and Humanities Research Division, ATINER \& Professor of History, Gordon College, USA.

- Dr. Patricia Hanna, Head, Philosophy Research Unit, ATINER \& Professor of Philosophy \& Linguistics, University of Utah, USA.

- Dr. Juliane House, Academic Member, ATINER \& Professor Emeritus/Distinguished Professor, Hamburg University/Hellenic American University, Germany/USA/Greece.

- Dr. Galina Bakhtiarova, Academic Member, ATINER \& Professor and Chairperson, World Languages and Literature, Western Connecticut State University, USA.

- Dr. Ioannis Christodoulou, Professor, Hellenic Open University, Greece \& Lecturer, Department of Classics and Philosophy, University of Cyprus, Cyprus.

- Dr. Michael M. Eisman, Academic Member, ATINER \& Professor, Temple University, USA.

- Dr. Abraham Panavelil Abraham, Professor, Department of Foreign Languages, University of Nizwa, Oman.

- Dr. Jean-Paul Kouega, Professor of English Language and Linguistics, University of Yaounde I, Cameroon.

- Dr. Nicholas Meihuizen, Professor, School of Languages, English Department, North-West University, South Africa.

- Dr. Suresh Frederick, Associate Professor \& UG Head, Department of English, Bishop Heber College, India.

- Dr. Ma Elena Gomez Parra, Academic Member, ATINER \& Associate Professor, University of Cordoba, Spain.

- Dr. Ana Pelosi, Associate Professor, Federal University of Ceará, Brazil.

- Dr. Ramunè Kasperavičiené, Academic Member, ATINER \& Associate Professor, Head of Study Programmes in Translation and Linguistics, Department of Modern Languages and Intercultural Communication, Faculty of Social Sciences, Arts and Humanities, Kaunas University of Technology, Lithuania.

- Dr. Victoria Tuzlukova, Academic Member, ATINER \& Head of Professional Development and Research Unit, Language Centre, Sultan Qaboos University, Sultanate of Oman.

- Dr. Roger S. Fisher, Academic Member, ATINER \& Assistant Professor, York University-TorontoOntario, Canada.

- Dr. H. Simour, Assistant Professor of English and Cultural Studies, Hassan II University, Casablanca, Morocco.

- Dr. Mary Ellis, Academic Member, ATINER \& Senior Lecturer, National Institute of Education (Nanyang Technological University), Singapore.

- Vice President of all ATINER's Publications: Dr. Zoe Boutsioli

- General Managing Editor of all ATINER's Publications: Ms. Afrodete Papanikou

- ICT Managing Editor of all ATINER's Publications: Mr. Kostas Spyropoulos

- Managing Editor of this Journal: Ms. Zoi Charalampous (bio)

\section{Reviewers' Board}

Click Here 


\section{President's Message}

All ATINER's publications including the e-journals are open access without any costs (submission, processing, publishing, open access paid by authors, open access paid by readers etc.) and are independent of the presentations made at any of the many small events (conferences, symposiums, forums, colloquiums, courses, roundtable discussions) organized by ATINER throughout the year. The intellectual property rights of the submitted papers remain with the author.

Before you submit, please make sure your paper meets some basic academic $\underline{\text { standards, }}$ which include proper English. Some articles will be selected from the numerous papers that have been presented at the various annual international academic conferences organized by the different divisions and units of the Athens Institute for Education and Research.

The plethora of papers presented every year will enable the editorial board of each journal to select the best ones, and in so doing, to produce a quality academic journal. In addition to papers presented, ATINER encourages the independent submission of papers to be evaluated for publication.

The current issue of the Athens Journal of Philology (AJP) is the fourth issue of the sixth volume (2019). The reader will notice some changes compared with the previous issues, which I hope is an improvement.

\section{Gregory T. Papanikos, President}

Athens Institute for Education and Research 
Athens Institute for Education and Research

\section{A World Association of Academics and}

Researchers

\section{$13^{\text {th }}$ Annual International Conference on Languages \& Linguistics 6-9 July 2020, Athens, Greece}

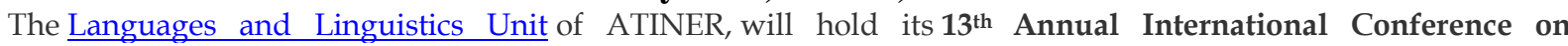
Languages \& Linguistics, 6-9 July 2020, Athens, Greece sponsored by the Athens Journal of Philology. The conference is soliciting papers (in English only) from all areas of languages, linguistics and other related disciplines. You may participate as stream organizer, presenter of one paper, chair a session or observer. Please submit a proposal using the form available (https://www.atiner.gr/2020/FORM-LNG.doc).

\section{Academic Members Responsible for the Conference}

- Dr. Valia Spiliotopoulos, Head, Languages \& Linguistics Unit, ATINER and Associate Professor of Professional Practice \& Academic Director Centre for English Language Learning, Teaching, and Research (CELLTR), Faculty of Education, Simon Fraser University, Canada

- Abstract Submission: 2 December 2019

\section{Important Dates}

- Acceptance of Abstract: 4 Weeks after Submission

- Submission of Paper: 8 June 2020

\section{Social and Educational Program}

The Social Program Emphasizes the Educational Aspect of the Academic Meetings of Atiner.

- Greek Night Entertainment (This is the official dinner of the conference)

- Athens Sightseeing: Old and New-An Educational Urban Walk

- Social Dinner

- Mycenae Visit

- Exploration of the Aegean Islands

- Delphi Visit

- Ancient Corinth and Cape Sounion

- More information can be found here: https://www.atiner.gr/social-program

\section{Conference Fees}

Conference fees vary from $400 €$ to $2000 €$ Details can be found at: https://www.atiner.gr/2019fees 


\section{Athens Institute for Education and Research \\ A World Association of Academics and \\ Researchers}

\section{$13^{\text {th }}$ Annual International Conference on Literature 1-4 June 2020, Athens, Greece}

The Literature Unit of ATINER is organizing its $\mathbf{1 3}^{\text {th }}$ Annual International Conference on Literature, 1-4 June 2020, Athens, Greece sponsored by the Athens Journal of Philology. The aim of the conference is to bring together academics and researchers from all areas of literature and other related disciplines. You may participate as stream leader, presenter of one paper, chair of a session or observer. Please submit a proposal using the form available (https://www.atiner.gr/2020/FORM-LIT.doc).

\section{Academic Member Responsible for the Conference}

- Dr. Stamos Metzidakis, Head, Literature Research Unit, ATINER \& Emeritus Professor of French and Comparative Literature, Washington University in Saint Louis, USA.

- Abstract Submission: 2 December 2020

\section{Important Dates}

- Acceptance of Abstract: 4 Weeks after Submission

- Submission of Paper: 8 June 2020

\section{Social and Educational Program}

The Social Program Emphasizes the Educational Aspect of the Academic Meetings of Atiner.

- Greek Night Entertainment (This is the official dinner of the conference)

- Athens Sightseeing: Old and New-An Educational Urban Walk

- Social Dinner

- Mycenae Visit

- Exploration of the Aegean Islands

- Delphi Visit

- Ancient Corinth and Cape Sounion

- More information can be found here: https://www.atiner.gr/social-program

\section{Conference Fees}

Conference fees vary from $400 €$ to $2000 €$

Details can be found at: https://www.atiner.gr/2019fees 


\title{
On Rimbaud's "Vowels," Again: Vowels or Colors?
}

\author{
By Victor Ginsburgh ${ }^{*} \&$ Stamos Metzidakis ${ }^{\dagger}$
}

\begin{abstract}
Arthur Rimbaud's sonnet Vowels presents a poetic vision based ostensibly on a quasipsychedelic or synesthetic experience. It has inspired writers, critics, painters, and singers for over a century mainly because of its often obscure form and content. From the first verse of the text, for instance, the author juxtaposes each of the normal five French vowels printed in capital letters with what appears to be a random choice of an "appropriate" color. As a result, the majority of readers assume that these colors somehow correspond, semantically speaking, to the selected vowels. In making such connections, however, our poet suggests that his specific fusion of basic colors and sounds is capable of generating not just one but multiple significations, be they religious, erotic, aesthetic, even anthropological. Yet the poem itself - an irregular French sonnet already derives much of its obscurity from another odd feature: the faulty order of French vowels used by Rimbaud: A to O instead of A to U or Y. Formal explanations are often cited to justify this so-called "mistake." This paper demonstrates that his poem hides a different interpretation of the words used to expand upon these sound/color combinations. After all, vowels are metonymically linked to sounds, since they constitute the minimal elements of the latter. Contemporary linguists have discovered, however, that in almost all languages, colors come in the same fixed order of words - Black, White, Red, Green and Blue - that Rimbaud proposes. Indeed, in countless documents created over millennia, people in dissimilar societies have tended to identify the same basic colors in the same sequence, for reasons we can only begin to explore here. This previously unnoticed coincidence thus provides further proof that Rimbaud's sonnet thematically conflates ideas about the historical Beginnings and Endings of various civilizations. Thanks to this chronological conflation, the poem also develops more effectively than previously thought three major themes: the Apocalypse, the Final Judgment, and the future of poetic language. Through its form and content, it thus specifically illustrates the future of French poetry, which Rimbaud compares elsewhere, paradoxically, to Ancient Greek poetry.
\end{abstract}

Keywords: ancient languages, Arthur Rimbaud, clairvoyance, symbolist poetics, synaesthesia, the Apocalypse of St. John

\section{Introduction}

Rimbaud wrote his famous sonnet Voyelles [Vowels] in 1871 or 1872 . But it was not published until 1883, when it began to cause quite a stir; one felt especially in bohemian circles frequented by writers like his elder and, at that point, erstwhile lover, Paul Verlaine. The poem continues moreover to make waves today. To a certain degree this is due to what is often thought to be an egregious error on his part. The so-called error concerns his (mis)use of French vowels, which consisted of switching the normal sequence of the penultimate and final vowels of his native tongue, $\mathrm{O} \& \mathrm{U}$. This deliberate reversal of regular order begins in the very first line of the poem and lasts until the very end. Instead of reproducing the canonical sequence A-E-I-O-U (and sometimes Y) taught to every

*Professor, Université Libre de Bruxelles, Belgium.

†Professor Emeritus, Washington University in Saint Louis, USA. 
schoolchild in France and many other countries where a similar alphabet is in effect, Rimbaud's text thus proposes a baffling new order: A-E-I- $U-O$. This anomaly has left countless scholars confused as to how they should understand it.

To help our own readers follow our arguments more carefully, we must first reproduce the full sonnet in French along with an English translation: ${ }^{1}$

\section{Voyelles}

A noir, E blanc, I rouge, $\mathrm{U}$ vert, O bleu: voyelles, Je dirai quelque jour vos naissances latentes:

A, noir corset velu des mouches éclatantes

Qui bombinent autour des puanteurs cruelles,

Golfes d'ombre; E, candeurs des vapeurs et des tentes,

Lances des glaciers fiers, rois blancs, frissons d'ombelles;

I pourpres, sang craché, rire des lèvres belles

Dans la colère ou les ivresses pénitentes;

U, cycles, vibrements divins des mers virides,

Paix des pâtis semés d'animaux, paix des rides

Que l'alchimie imprime aux grands fronts studieux;

O, Suprême Clairon plein de strideurs étranges,

Silences traversés des Mondes et des Anges:

-Ô l'Oméga, rayon violet de ses Yeux!

And here is a recent English translation by A.S. Kline in $2003:^{2}$

\section{Vowels}

A black, E white, I red, U green, O blue: vowels

Someday I'll talk about your secret birth-cries,

A, black velvet jacket of brilliant flies

That buzz around the stenches of the cruel,

Gulfs of shadow: E, candour of mists, of tents,

Lances of proud glaciers, white kings, shivers of parsley:

I, purples, bloody salivas, smiles of the lonely

With lips of anger or drunk with penitence:

\footnotetext{
${ }^{1}$ This version conforms to the autograph manuscript by Rimbaud. See Rimbaud (2009: 167). The volume includes two other versions on pp.168 and 169. The first is a "Copie de Verlaine", the second was published in "Les Poètes maudits. II. Arthur Rimbaud," de Verlaine, "Lutèce," 5-12 Octobre 1883. That so much of what Rimbaud wrote comes down to us via copies of the manuscripts he produced raises all sorts of questions, of course, about their authenticity, accuracy, etc. Nonetheless, everything we discuss here is based on well-known and widely accepted publications that appeared after our poet abandoned creative writing all together, except for his rather abundant letter correspondence.

${ }^{2}$ Poetry in translation (n.d.) Rimbaud, Selected poems. Retrieved from https://bit.ly/31Vz8WV. [Accessed 24 April 2019].
} 
$\mathrm{U}$, waves, divine shudders of viridian seas,

Peace of pastures, cattle-filled, peace of furrows

Formed on broad studious brows by alchemy:

O, supreme Clarion, full of strange stridencies,

Silences crossed by worlds and by Angels:

$\mathrm{O}$, the Omega, violet ray of her [or his] Eyes!

Many incompatible solutions to this vowel enigma have been put forth, including one (Metzidakis 1988) by a co-author of the present article. The title of his earlier article (Did Rimbaud really know his alphabet?) rhetorically asked whether the great French Symbolist had in fact made an egregious mistake and whether he actually knew his alphabet. The textual impetus for this tongue-in-cheek article title was precisely the troubling error in the order of capital French vowels. This co-author's true argument, however, was that no such error exists and that by choosing this odd vocalic order, Rimbaud succeeded in creating a different alphabet from the one to which he and his native speaker readers were accustomed. The reason behind his unusual stylistic tactic was that it formed part of a larger strategy for the entire poem; one that allowed the young writer to conjure up an original vision of a radically different mode of expressing himself through a "systematic derangement of normal senses." The latter phrase is our translation of the celebrated formula found in his later editorially compiled Lettres $d u$ Voyant or Letters from the Seer, in which he describes both his writing practice and preferred life style qua Seer as requiring just such a dérèglement systématique de tous les sens. Later on we will provide more details on this specific vision.

The other co-author of the present essay, who usually works in fields outside of philology per se, became fascinated with questions that more often pertain to diachronic linguistics and, even more generally, anthropology. Thanks to his relatively new found interest, he recently began reconsidering the historical appearance of particular sequences of words designating colors in some of the 6,000 to 7,000 languages - nobody knows exactly how many - that are either still spoken or have disappeared at some point after the supposed destruction of the Tower of Babel in the Land of Shinar, Babylonia. One will recall that following that Biblical event people were reportedly dispersed over the face of the earth, at least according to Genesis (11:1-9). But, since God suddenly made them forget the only language they had learned before this diaspora, the people had to start all over again to recover their language, their words, including those that signify colors in their "new" languages. Though they were naturally able to distinguish the fact that to a large extent trees were (very often) green, and that flowers tended instead to exhibit more shades of reds, blues, yellows, etc., postdiluvian people had to (re)invent the relevant words.

It just so happens, however, that the words they discovered - or merely recreated - fell into the following fixed order, regardless of their tribe: Black and White first, followed by Red, Green and Blue. Step by step, they forged other words for some of the infinite number of related colors the human eye can distinguish. Perhaps this is also the order in which Rimbaud discovered them himself or simply learned them in school. In any case, the co-authored 
essay offered here will now first present a few of the compelling solutions philologists have previously put forth to resolve these enigmatic vowel-color connections. The recent anthropological find just mentioned will then allow us to add yet another intriguing level or dimension to this literary puzzle for future scholars to consider and explore further.

\section{Philologists at Work}

Many readers of Vowels have wondered, for example, whether, metrically speaking, the poet simply wanted to avoid the so-called hiatus problem described in French classical versification when inverting the $\mathrm{O}$ and $\mathrm{U}$. Avoidance of the hiatus constituted a well-known "rule" that was widely respected by major poets writing in that language until at least the mid $-19^{\text {th }}$ century. What the rule prohibited was the placement of consecutive vowels at the end of one word and the beginning of the next in "proper" French verses. Thus, if the initial line in Rimbaud's poem had read "...O bleu $U$ vert" the proximity of the sounds bleu $\& U$ would have violated this norm. Many critics therefore opine that this is why he made this "mistake." For countless others scholars, the said anomaly resulted instead from his typical "bad-boy" behaviour. According to this reading, by attempting to propose a new type of alphabet in lieu of the usual one, he was merely engaging in another of his infamous provocations. Still other critics have remarked that in changing the traditional vocalic order, Rimbaud underscores the Greco-Roman origins of the French alphabet rather than repeat the Gallicized one he and his fellow writers and countrymen all learned in school. And indeed, one cannot help but notice that in the final line of the sonnet, the poet explicitly evokes Greek vowels and reprises the capital letter O, calling it, "Omega." As it bookends the implied Alpha that initiates the text, this vowel explicitly refers to a well-known, apocalyptic description of Jesus Christ, who describes himself in St. John's vision, as the beginning and end, the Alpha and Omega, of human history itself.

Throughout the poem, the reader thus encounters the same faulty openingline vocalic sequence (A to $\mathrm{O}$ ) structuring the other lines. In the process, the author seems intent on developing previously unknown semantic and metaphorical connections between vowels and - of all things - colors. He accomplishes all this by immediately pairing or fusing each vowel he mentions with a "corresponding" color. As a result of such inventiveness, Rimbaud's sonnet is often seen as a poetic illustration of the mental phenomenon known as synaesthesia. In fact, so common is this belief that even serious contemporary researchers currently working on mapping out the workings of the brain and its synapses cite this very same poem when attempting to explain such mental aberrations. A propos of the same text, it is even said that Rimbaud confided the following to his friend Ernest Delahaye (as cited in Dehaene 2009: 215): "I believe that I sometimes saw or felt in this manner, and I say it, I talk about it, because I find it just as interesting as anything else." Yet Rimbaud himself never provides any full length, logical explanation 
for the apparent randomness of the vowel-color pairs, which already form the first verse:

A black, E white, I red, U green, O blue

So, is he primarily trying to stress supposedly new semantic connections between sounds (vowels) and colors, or to suggest something else, something more?

Nor does he ever explain the potentially innumerable literal or figurative connections readers have made or might make between them, as we, too, shall do presently. One other such extensive, nearly exhaustive reading, was published years ago by the now deceased and controversial anti-Semite, Robert Faurisson. In an influential, albeit highly debatable, study published before his darker racist side was revealed, Faurisson (1961) argued that the sonnet is primarily erotic and used evidence like the visual shapes, not sounds, of the vowels that compose it to prove his points. One major problem with his approach, however, is that it requires readers to re-imagine the vowel $\mathrm{E}$, for instance, as standing on its side in order to represent a woman's breasts. Or to reread the title Voyelles as Vois-elles, i.e. See them, meaning: This title invites or instructs us to see all the other parts of the woman portrayed in the sonnet, just as students of French Literature learn to observe and admire similar feminine traits in Renaissance love poems known as blasons. The truth is, however, that little about this poem really compels us to read it this way, or to reject any number of other extraordinary critical interpretations or reconfigurations of the signifiers which actually appear on the page. Nor, finally, does Rimbaud recommend certain readings or interpretations of said connections over others, although he does provide clues which the aforementioned article (Did Rimbaud really...) brings together to build its central argument.

In any case, along the otherwise traditional fourteen lines of the sonnet form, the text assumes an overall acrostic shape running down the page in the following strikingly visual manner:

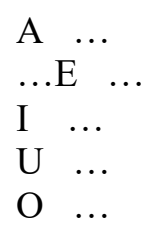

By apostrophizing the final vowel in this seemingly Hellenized sequence in the fourteenth line of his poem - "Ô, l'Oméga" - Rimbaud thus makes clear that on some level, as we've said, he has chosen to re-imagine the normative order of French vowels as Greek ones. Why? To summarize and recapitulate our earlier essay here, this is primarily due to certain crucial, intertextual references. Principal among them is the allusion to the figure of Jesus Christ as he appears in the prophetic biblical text commonly known as the Book of Revelations or the Apocalypse of Saint John. In linking these two works, Rimbaud illustrates, metonymically, the future of all French poetry. His sonnet manages to do this, first, because both texts speak of things that shall come to pass; and second, 
because both continually mention colors whenever sounds (or vowels, which, after all, are the building blocks of most human sounds) are evoked.

Additionally, in the biblical prophecy Jesus says of himself several times, "I am the Alpha and the Omega [...] the beginning and the end." The rationale for Rimbaud's "error" then becomes much clearer, since elsewhere in his work and correspondence the poet describes himself, as well as his idealized vision of the future poet, as a Seer or Voyant in French. He also explicitly states that in the future the ideal language for French poetry will again be a little like Ancient Greek poetry // "... ce serait un peu la Poésie grecque." Last but not least, the final two words of the sonnet are "Ses Yeux [His Eyes]." Those words are significant because, while alluding to the eyes of God, this semantically potent phrase has an extra formal advantage pertinent to the poem's major theme(s): it contains yet another capitalized vowel, the letter Y, one which supplements the other five vowels in the earlier sequence. It therefore compensates, as it were, for the "missing" (semi) vowel Y, just as Rimbaud's poetic/prophetic vision comes to a close.

Obviously then, we must recognize that Rimbaud was neither illiterate nor unsure about the correct alphabet to use for his visionary sonnet. Instead, he composed it for reasons about which he may have been either conscious or unconscious. It really does not matter much which, since the alert reader inevitably makes the connections. In the former case (conscious), he might simply have put into poetic use some exceptional knowledge he had acquired during his adolescence while experiencing either an actual episode of synaesthesia, or more likely, as a kind of quasi-mystical "illumination." In fact, later in Rimbaud's relatively short writing career, this type of vision took many other textual shapes and helped him formulate his inspired eponymous collection of prose poems.

\section{Linguists at Work}

A Levinasian reading of Blanchot's novellas shall answer the questions raised above by examining the following: First, how Blanchot's negative discourse allows for a double parole to occur and for the text to take the form of the face of the other - a speaking entity - that according to Emmanuel Levinas (19061995) imposes itself onto the listener, in our case, the reader. Second, how the author's desubjectivized narrators fuel the text's double parole all the while insinuating that the truth of the text is to be found neither in the plot, nor in its words but only in "the silence of essence, essence or essencing (Wesen) that resounds in [each] poetic word" (Llewelyn 2008: 134) and that resonates in the reader through his or her engagement with the text. Third, how Blanchot's textual fragments create an experience of the Levinasian il y a that fosters "the secret of the birth (connaissance) of thought" (Levinas 1987: 125) in the text, and allows the reader to develop a better understanding of the self as well as of "the face that speaks" (Levinas 1987: 120), the textual artifact, through active engagement with the text. 
In the latter (unconscious) case, however, he may have been led to these peculiar vowel-color connections merely because he was doing what people throughout the world have evidently always done. What we mean is that Rimbaud may also have just correctly guessed the order in which words for colors were first discovered and articulated by our ancestors and their descendants. According to the Old Testament, one of the major sources of Western, Judeo-Christian tradition which Rimbaud certainly studied, readers learn that after God destroyed the Tower of Babel, His people all started to speak different languages. But though humans can distinguish several millions of color differences, since the range is made of a three dimensional continuum defined by the wavelength of reflected light, the quantity of reflected light, and the dilution of the color with white (brightness) or its difference from black (for instance, light or dark blue), in his wisdom, God distributed the words for colors in a very scant way. Some populations only know Black and White; others add Red to this. If the language contains four words, the fourth is either Green or Yellow. Languages that contain five words have both Green and Yellow. Then comes Blue. The number of terms used to denominate basic colors thus varies across languages. English has eleven words that everyone knows - Black, White, Red, Green, Yellow, Blue, Brown, Orange, Pink, Purple, Grey - while the Bolivian Amazonian language, Tsimane, has only three - Black, White and Red.

But there is more than the fact that populations have only a selected number of words for colors. It also turns out that, among the words constitutive of our many and varied languages, one almost universally discovers the same fixed order of words - Black, White, Red, Green, and Blue - found in Rimbaud's sonnet: A black, E white, I red, U green, $\mathrm{O}$ blue. In the various languages, there is no word Red before Black and White, no words for Green or Blue, before there is a word for Red...

To be sure, this unexpected coincidence requires more explanation and justification. So here is what we can state with some scientific certainty today. Berlin and Kay (1969) showed that the words for colors appear in a relatively fixed order across cultures and languages. Some populations have words for Black and White only, for instance. Yet, although they could probably distinguish other colors as well, these same populations had no specific words for them.

As already mentioned, Tsimane has only three colors - Black, White and Red. A population that has a word for Red, furthermore, already has words for Black and White. The reverse order never occurs, however. Red was also followed by Green or Yellow in some civilisations or Yellow and Green in others; then came Blue. The terms for Brown or Purple appear only after the distinction between Green and Blue.

Monolingual Zuni speakers and English speakers have the same color categories with the exception of Yellow and Orange for which Zunis have only one term while English speakers have two (Lenneberg \& Robert 1956).

In some languages (a dialect of Amazigh, the language of Berbers in North Africa), there is only one term for Green and Blue. On the other hand, in the Bantu language, Swahili, Green and Blue have no words. They are described respectively by rangi ya mayani (the color of grass), and rangi ya angwa (the color of the sky). 
Pashto, an Indo-Iranian language spoken in Afghanistan and Pakistan, uses the word shin for both colors. But when it gets difficult to understand to which color shin relates, they add "plants" or "sky" like in Swahili. Greek makes a difference between a light shade of blue called ble $(\mu \pi \lambda \varepsilon)$ and a darker one called ghalazio ( $\chi \alpha \lambda \alpha$ $\left.\zeta_{10}\right)$. According to Thierry et al. (2009), this leads to "faster perceptual discrimination of these colors in native speakers of Greek than in native speakers of English...which establishes an implicit effect of language specific terminology on human color perception."

Brown and Lenneberg (1954), and Lenneberg and Roberts (1956) were among the first to use experiments to investigate the idea that lexical differences result from cognitive differences. Berlin and Kay (1969) found that colors are hard-wired in our cognitive system. The debate switched from one extreme to the other and can be summarized by the following two questions formulated by Kay and Regier (2006):

1. Is color naming across languages largely a matter of arbitrary linguistic conventions?

2. Do cross-language differences in color naming cause corresponding differences in color cognition?

Many papers followed choosing one of the two directions or even creating new ones. Gibson et al. (2017), for instance, show that the problem has much less to do with perception than with usefulness of a color: "It is now established that native language affects one's perception of the world. However, it is unknown whether this effect is merely driven by conscious, language-based evaluation of the environment or whether it reflects fundamental differences in perceptual processing between individuals speaking different languages." And three years after Kay and Regier (2006) formulated the two questions quoted above, Regier and Kay (2009) changed the order of their names and responded by: "With respect to question (1), color names do influence color perception - but primarily in the right visual field, and less so in the left. With respect to question (2), color naming across languages does reflect universal tendencies, as shown in earlier work - but also some degree of local linguistic convention."

After he wrote this poem and many others, Rimbaud left for Abyssinia, knowing full well that French had eleven words that the rest of us all know: Black, White, Red, Green or Yellow, Green and Yellow, Blue, Brown, Orange, Pink, Purple, and Grey; all other words are mere nuances or shades. By that we mean that a word like Yellow is what we may call a fugitive color, since when it meets Blue, it becomes Green. And we surmise that as Rimbaud was seemingly concerned in this particular poem with something basic, something originary, he preferred to ignore it.

Yet, other nuanced, fugitive colors do appear elsewhere in the body of his published works, including Vowels itself. Rereading it quickly reveals the explicit presence of at least shades of purple, violet, and viridian. The important difference though is that they are not attached immediately to any of the vowels cited, as we see in the text's first line. Rather they appear in the lyrical descriptions and expansions of each of the five vowel/sound-color couplings. In the very first of his 
"Illuminations" too, titled Après le Déluge [After the Deluge], for example, Rimbaud evokes several other colors and shades of color such as Purple, Blue, even an entire enchanted rainbow in which he bathed his personal splendid vision of a wholly cleansed and utterly renewed universe: a symbolically rich goal projected by a truly revolutionary artist for his own longed-for paradise on earth. Yet, there as well we find no strict merging or seamless correlations established by the author between the principal vowel/sounds and colors in our target poem. Something important, something unique, therefore, seems to have been at stake in this legendary, if brief, work.

\section{Conclusion}

It is difficult to imagine then how in a text he specifically titled Vowels Rimbaud would have used any colors other than the most basic, common, and universal. For his visionary text clearly has Biblical overtones, along with originary and teleological images. Images, in other words, that dramatically depict the beginning or end of a given civilization. Our poet was also limited, by definition, to the five actual vowels in the French language. As a result, there were obviously only five colors he had at his disposal to combine with an equal number of vowels. Thanks to the new linguistic evidence about early language formation presented above, however, we can now comprehend better and appreciate much more why he picked the particular order(s) he did, not only for the latter but also the former.

\section{References}

Berlin B, Key P (1969) Basic Color Terms: Their Universality and Evolution. Berkeley: University of California Press.

Brown R, Lenneberg E (1954) A study in language and cognition. The Journal of Abnormal and Social Psychology 49(3): 454-462.

Dehaene S (2009) Reading in the Brain: The New Science of how we Read. New York: Penguin Books.

Faurisson R (1961) A-t-on lu Rimbaud? Bizarre 21-22. Printed in book form in Paris: Jean-Jacques Pauvert.

Gibson E, Futrella R, Jara-Ettingera J, Mahowalda K, Bergena L, Ratnasingamb S, Gibsona M, Piantadosic S, Conwayb B (2017) Color naming across languages reflects color use. Proceedings of the National Academy of Sciences 104, 10785-90.

Kay P, Regier T (2006) Language, thought and color: recent developments. Trends in Cognitive Sciences 10(2): 51-54.

Lenneberg E, Roberts J (1956) The language of experience: A study in methodology. International Journal of American Linguistics, Memoir no. 13.

Levinas E (1987) Time and the Other. Duquesne University Press.

Llewelyn J (2008) Levinas and Language. The Companion to Levinas. S Critchley, $\mathrm{R}$ Bernasconi (Eds.). Cambridge, UK: Cambridge University Press.

Metzidakis S (1988) Rimbaud ignorait-il son alphabet? Parade Sauvage Bulletin Revue d'Etudes Rimbaldiennes 4(Mars): 56-64. Expanded and translated from Did Rimbaud really know his alphabet? Nineteenth-Century French Studies 14(3-4): 278-283. 
Regier T, Kay P (2009) Language, though and color: Whorf was half right. Trends in Cognitive Sciences13(10): 439-446.

Rimbaud A (2009) Oeuvres complètes (Complete works). Paris: Editions Gallimard, Bibliothèque de la Pléiade.

Thierry G, Athanasopoulos P, Wiggett A, Dering B, Kuipers J-R (2009) Unconscious effects of language-specific terminology on pre-attentive color perception. Proceedings of the National Academy of Sciences of the United States of America $106,4567-4570$. 


\title{
The (Silent) Articulation of Otherness: Maurice Blanchot's Double Parole in Death Sentence, Awaiting Oblivion, and Madness of the Day
}

\author{
By Alexandra Reuber
}

\begin{abstract}
This article examines Maurice Blanchot's articulation of self vs. other in his novellas, Death Sentence (1948), Awaiting Oblivion (1962), and Madness of the Day (1973). Marked by a fragmented narrative structure and negative discourse, Blanchot's novellas are other as they appear to be incomprehensible and unfinished. Yet, their double parole of saying nothing but everything, allows for his texts to take the form of Levinas's face of the other, a speaking entity that imposes itself onto the (reading) subject and, thus, challenges readers to reflect on the notion of becoming as opposed to being through the engagement with the work.
\end{abstract}

Keywords: Double parole, Face of the other, Negative discourse, Selfhood, Silence

\section{Introduction}

Maurice Blanchot (1907-2003), for as long as he wrote, meditated on selfhood through writing and, by doing so, on writing itself. For Blanchot, writing raised the question of becoming as opposed to the notion of an existing ideal or absolute form of being, thus, nullifying the idea of the completed (literary) text and of the fully developed self.

The author's three novellas, Death Sentence (1948), Awaiting Oblivion (1962), and Madness of the Day (1973), illustrate this annihilation of an existing ideal or absolute form of text and being through non-linear plot outline, lack of fictional visualization, highly fragmented narrative structure, and the abstract use of language. Not the product or completeness of the work but the "quest for the work" is of interest (Blanchot 2003: 200); a quest that expresses itself in an almost incomprehensible, almost negative discourse that is tightly connected to the quest for selfhood and a developing understanding of the self. As a consequence, this lack of completeness of the work, which finds its counterpart in the presence of an insufficiently developed self, often leads to a breakdown of communication between Blanchot's text and reader. In addition, it triggers an apparent silence and an aura of waiting within the text and its fictional characters, as well as between text and reader.

The resulting fragility of the work and the notion of the self then produces an everlasting presence of an inexplicable unknown that neither the reader nor the text ever seems to be able to grasp or define fully. It is a presence that silently points "beyond the borders of the text" (Hill 2012: 143) but somehow cries out from within the work demanding a new beginning of the just ended communication through the (re)examination and (re)evaluation of text, language, and self.

\footnotetext{
${ }^{*}$ Senior Professor of Practice, Tulane University, USA.
} 
It is only via this double parole that manifests itself in the opposing concepts of communication vs. silence, ending vs. beginning, disappearance vs. reappearance, and presence vs. absence that Blanchot's text and characters come alive, express their own partial truth, formulate their own set of questions, and impose themselves as something other onto the reader. In other words, it is this interplay between the textual source (artistic pole) and the reader (the text's aesthetic pole) that is at the heart of Blanchot's double parole and his literary creations. As a consequence, Blanchot's texts mark the end of communication as the beginning of another discourse that generates new knowledge within the text and one's self; knowledge that can neither be found within the literary artifact, nor gained from a finished text alone. It is the knowledge that can only result from the quest for what is hiding behind the silence of the work: a process that is marked by the dissociation from the textual object and its language whose meaning, as Blanchot explained in his monograph The Work of Fire (1949), "derives not from what exists, but from its own retreat before existence" (1995: 324).

\section{Literature Review}

Literary critics John Gregg, Anne McConnell, Paul Davies, and Ethan Kleinberg, only to name a few, have discussed this juxtaposition of appearance and disappearance, of presence and absence in Blanchot's work. John Gregg, for example, clearly states that in Blanchot's writing "the accent is placed on the way in which something is said and not on what is said," thus, differentiating between the work's "material presence" and its "ideal absence" (1994: 18).

Both Anne McConnell in her monograph Approaching Disappearance (2013) as well as Ethan Kleinberg in his book Generation Existential. Heidegger's Philosophy in France (2005) recognize the domineering notion of absence that marks Blanchot's work. McConnell calls this absence a disappearance, a process that indicates a movement towards nothingness and negation, a process that Blanchot connects with writing itself as it is always "going towards itself, towards its essence, which is disappearance" (Blanchot 2003: 195). Hence, Kleinberg is right stating that in Blanchot's text "the word is both the beginning and the end" (2005: 215).

Through his essay "The Work and the Absence of the Work" (1996), Paul Davies joins this discourse focusing on the process of the disappearing and becoming of the work, a process that is always marked by a present absence or absent presence, by "an obligation to continue writing" (1996: 92), because the idea, the word, yet the entire work is always bound to another idea, word, and work. Hence, any work (silently) articulates its absence, its solitude, its otherness, its constant state of becoming and disappearing.

Yet, despite the fact that Gregg, McConnell, Kleinberg, and Davies recognize the existence of the double parole in Blanchot's work, their critical discourse neither explains its functionality, nor evaluates how this particular "presence of absence" (Gregg 1994: 19) creates meaning itself. Moreover, Gregg, McConnell, Kleinberg, and Davies omit looking at the three novellas Death Sentence (1948), 
Awaiting Oblivion (1962), and Madness of the Day (1973); three literary works that are highly marked by Blanchot's double parole, and which may hold the answer to the understanding of Blanchot's negative discourse and work as a whole. This said, they overlook to ask the following questions: First, what role does Blanchot's negative discourse play in generating this double parole that seems to say nothing but actually expresses everything via a non-explanatory text that demands the reader's cooperation at all times and only comes alive through the reading process $?^{3}$ Second, what knowledge does the reader gain from engaging with an unfinished and highly fragmented text that seems to be incoherent to the degree of being incomprehensible? Third, what broader implications does the recognition of the existing double parole have for Blanchot's work as well as for us readers?

\section{Methodology}

A Levinasian reading of Blanchot's novellas shall answer the questions raised above by examining the following: First, how Blanchot's negative discourse allows for a double parole to occur and for the text to take the form of the face of the other-a speaking entity-that according to Emmanuel Levinas (1906-1995) imposes itself onto the listener, in our case, the reader. Second, how the author's desubjectivized narrators fuel the text's double parole all the while insinuating that the truth of the text is to be found neither in the plot, nor in its words but only in "the silence of essence, essence or essencing (Wesen) that resounds in [each] poetic word" (Llewelyn 2008: 134) and that resonates in the reader through his or her engagement with the text. Third, how Blanchot's textual fragments create an experience of the Levinasian il y a that fosters "the secret of the birth (connaissance) of thought" (Levinas 1987: 125) in the text, and allows the reader to develop a better understanding of the self as well as of "the face that speaks" (Levinas 1987: 120), the textual artifact, through active engagement with the text.

\section{Analysis and Discussion}

\section{Maurice Blanchot and Emmanuel Levinas: Encountering the Face of the Other}

When discussing the notions of neutrality, alterity, and transcendence of being through writing, Emmanuel Levinas's influence on Maurice Blanchot cannot be missed. Both men deny the existence of the absolute form of being, which in Blanchot's case translates to a denial of the existence of a fully completed text on

\footnotetext{
${ }^{3}$ It can be argued that while taking the risk of reading a fragmented text, the reader experiences a sense of waiting for the true meaning of the work, which inadvertently forces the reader to slow down and to engage actively with the text. As a consequence, the reader reflects on the state of being and becoming of a textual product as well as of his/her role in life itself. Not the final textual product then is of importance, but rather the experience of reflection and its consequential deeper awareness of the text and of the self is the premise of Blanchot's texts. In this sense, his texts appear to say nothing, but actually saying everything.
} 
the one hand, and the encouragement to develop a process of "thinking that goes beyond the realm of being" (Levinas 1987: 13), on the other. This leads to the recognition of a transcendental, unidentifiable, neutral essence that expresses itself via the "ambiguity of the Saying and the Said" (Critchley 1996: 114). Not the finished book or the Said is of importance, but the space that results from the ambiguity and the "interruption of language" (Sealey 2013: 441) that finds articulation in the inexpressible and unnamable. Hence, the main interest relies on something other than complete representation.

In Levinas's case, this other takes the form of the autrui, the other face that looks at and talks to me. As such it is an entity that refers to you, "the other person, [...] that each of us encounters directly, or experiences the traces of, every day" (Young 2017). This entity is an external social other, "the clearest and most potent revelation that I am not everything-that everything does not belong to me and that my consciousness does not encompass everything" (Young 2016: 2). However, this other is not one specific person. It is actually anybody other than me. Hence, it has to be understood as an unidentified and unidentifiable existence that imposes itself onto my ego's world, and when doing so, challenges and influences my understanding of selfhood. In short, this other presence, also referred to as the face of the other, "cannot be captured or grasped and is therefore, in the strictest sense of the word, incomprehensible" (Peperzak 1993: 21). It is something that transcends a defined existence with a fixed identity. It is something that simply is.

Maurice Blanchot's novellas encapsulate the presence of this other and its resulting notion of otherness in several ways. His fictional characters, for example, express themselves in seemingly empty dialogues whose sentences are often incomplete or appear in a sequence of questions that remain unanswered. Moreover, its thoughts are often fragmented and remain undeveloped, and the choice of vocabulary is repetitive triggering an overall feeling of "otherness and strangeness" (Waldenfels 2008: 63). The following dialogue between the anonymous narrator and his female interlocutor in Awaiting Oblivion exemplifies these observations well:

"He watched over the forgetting where she was leading him, by a calm movement that came from forgetting. Forgetting, forgotten. 'If I forget you, will you remember yourself?'-'Myself, in your forgetting of me.'-'But is it I who shall forget you; is it you who will remember?'-'Not you, not I: the forgetting will forget me in you, and the impersonal remembrance will efface me in you, and the impersonal remembrance will efface me from that which remembers."' (Blanchot 1997: 38)

Instead of finding answers to these questions in the text, this dialogue rather provokes additional questions in the reader: What does this dialogue, which is composed of incomplete and repetitive questions, entail? Does it focus on the forgetting of the other, of the self, or of the other as part of the self? What does the repetitious use of the verb "to forget" mean for this dialogue, for the text as a whole, and maybe even for Blanchot's entire work? What shall we not forget? What shall we remember?

Since Blanchot leaves questions unanswered, readers often judge his writing as incomprehensible or meaningless. Literary critics, such as Donald G. Marshall 
and Rhys Tranter, even define Blanchot's writing as radically defective (Marshall 1986: 226). To them, the writing consists of "scattered fragments of ordinary experience" (Marshall 1986: 225), which are so difficult to understand that the resulting text seems to disappear. As a consequence, Blanchot's texts are other because they "invariably withdraw from themselves to cast doubt on their own thinking or inherited terms of reference" (Hill 2012: 143). In reference to the quote above (Blanchot 1997: 38), the text seems to call into mind the act of remembrance of one's true self, yet casts doubt on this thought by focusing on the act of forgetting of the self in relation to the other.

Like Levinas's speaking other that imposes itself onto the listener, Blanchot's fragmented text imposes itself onto the reader, demanding an ongoing reading process to discover its meaning and truth. However, due to the texts' fragmentation and abstract use of language, the reading process is obscured, and the reader becomes hostage to the engagement with the written artifact. In other words, the reader gets consumed in the everlasting "quest for the work" (Blanchot 2003: 200) implying that the reading process will never be complete because, as Levinas once stated, "the Saying (le dire) can never coincide with any Said (le dit)" (Peperzak 1993: 29).

Since the Said will always be called into question, the text's content and dimension will always surpass its reader, meaning that the engagement with the other does not necessarily lead to the discovery of the truth, but to a "higher dimension that commands us" (Peperzak 1993: 43) and that silently forces us as readers to return again and again to the written artifact and to look beyond its written surface. The outcome is an endless rereading that will always be marked by the reader's confusion, misunderstanding, and disorientation leading to an eventual breakdown or death of communication between the text and the reader.

This breakdown of communication and its subsequent silence is very characteristic of Blanchot's novellas Death Sentence, Awaiting Oblivion, and Madness of the Day. For example, in Death Sentence, the anonymous first-person narrator discloses two unrelated events. In the first part, the narrator describes his peculiar relationship with J., a woman whose medical condition confines her to bed, to excruciating pain, and to injections of morphine until she dies. In the second half of the novella, the narrator conveys his irregular encounters with his neighbor Colette as well as with the translator Nathalie and her young daughter Christina. Even though identified by name, the three women lack any further characteristic features and appear disconnected from their surroundings. Whether Colette is "crying violently" in her room, or Nathalie is described as "[finding] herself wrestling with strange feelings, in the room" (Blanchot 1978: 48, 50), neither women, nor surrounding space find further discussion. One could even say that the missing characteristics of the female character reflect the non-existing description of their apartments and vice versa. Both, woman and rooms, remain "more or less empty and neglected" (Blanchot 1978: 55).

This missing information is aligned with Blanchot's understanding of neutrality and Levinas's cognizance of the nakedness of the other. According to Levinas, the other's "beauty, talents, performances, roles, or functions" (Peperzak 1993: 20) are of no importance to the beholder. Only the fact that the other exists 
is of importance, because its simple existence signifies already that I am not everything. The revelation of any particularities of the other would lead "me away from the "absolute otherness" that is [expressed, presented, and] at stake" (Peperzak 1993: 20). Hence, neutrality is the key to maintain the notion of absolute otherness. In this particular case, otherness of the literary artifact.

The resulting lack of information prompts questions such as: Who is the narrator? Who is J.? What is her medical condition? Who are the other women? What is their relationship to each other? Or, which message does the text attempt to relate? The text itself does not answer any of these questions, just sparks them in the reader. In this sense, Blanchot's text as a whole becomes the literary manifestation of Levinas's naked face of the other that "interrupts and disturbs the order of my, ego's, world" (Peperzak 1993: 20). It imposes itself onto me, the reader, in the form of a narrative composed of an unlimited number of questions and fragments that somehow seek adherence and completion through the reading process.

In Madness of the Day, it is yet another non-identified male narrator who, in his journal-like entry, alludes to his travels, solitude, relationship to others, physical assault due to which he almost lost his sight, and the meaning of life, without ever revealing any connection between or deeper meaning of these individual components of his discourse. Instead of providing detailed information, the first-person narrator often ends his discourse with a question. He asks: "Why all that? Who was being questioned? Who was answering?" (Blanchot 1981: 1617). By doing so, he engages the reader in his monologue illustrating his "hellish unfreedom" (Wellbery 1996: 159) from life in general, and from the other to which the I is bound, in particular. In addition, through the pronunciation of questions, the narrator closes and reopens his account. He actually includes the reader in the creation of his own story, because he himself refuses to tell a story. He states unmistakably: "No. No stories, never again" (Blanchot 1981: 18).

The narrator's conscientious choice of silence then shifts the responsibility onto the reader and requests him/her to answer all the questions that have been left unanswered by the text, making the reader the speaking subject. In other words, it is "the other's command [that] commands me to command" (Thomas 2004: 115). The impossibility to complete this command results in the only outcome possible: the formulation of an endless number of questions that originate from a breakdown of communication between the text and the reader.

Awaiting Oblivion, Blanchot's most experimental narrative, generates a similar breakdown of communication. It is a story about an encounter of a man and a woman, "anonymously known as Il and Elle, respectively" (Khatab 2005: 83). At the beginning of this story that "revolves around their relationship" (Khatab 2005: 83), the woman states loud and clear: "I will not tell you everything; I will tell you almost nothing" (Blanchot 1997: 11). This contradictory statement holds true for the remaining 80 pages of the text, which Blanchot fills with a seemingly incomprehensible and empty dialogue that finds its architectural representation in the hotel's sparsely furnished room "reduced to the bare essentials" (Gregg 1997: x). 
Here it can be argued that hotel room and conversation express a certain distance to and refusal of the material and emotional world, which already shines through in the woman's repetitive statement: "I will not tell you everything; I will tell you almost nothing" (Blanchot 1997: 11); a statement that, through its articulation of opposing concepts-everything vs. nothing-also creates a sense of ambiguity, non-comprehension, and hesitation. This hesitation and noncomprehension are fueled by additional questions that again remain unanswered: "Why do you listen to me as you do? Why, even when you speak, do you keep listening? Why do you attract in me these words that I must then say? And never do you answer; never do you make something of yourself heard" (Blanchot 1997: 4). This list of unanswered questions followed by the reproach of not making oneself heard underlines "the emptiness of the voices" (Blanchot 1997: 7) as well as the emptiness of the hotel room in which they are articulated. Moreover, it illustrates the characters' refusal to engage in a meaningful discourse.

The man's question "Why do you attract in me these words that I must then say?" (Blanchot 1997: 4), initially directed at the woman in the hotel room, becomes then a question the entire text directs at its reader. By doing so, the text imposes itself onto the reader and demands its completion through the reading process. Thus, it can be argued that the existence of the text is the revelation of the existence of the other that imposes itself on me, the reader, and that puts me in question. Hence, the narrator of each novella exposes me to the inescapable and incontrovertible demand of and answerability to the other (Young 2016), the invisible force that "regards me and speaks to me" (Peperzak 1993: 64) silently about the rewriting or completion of the fragmented text through the reading process.

As a result, it is not important what was said, but that something was said, because Levinas's "autrui me parle" (Peperzak 1993: 20) and forces me, the reader, to respond to the other, the highly fragmented text filled with "abstract words, which [evoke] nothing" (Blanchot 1997: 8). Only when interacting with the artifact, the text comes alive and brings about a subsequent set of questions that applies to all three of Blanchot's novellas: Will the reader ever be able to complete what Blanchot calls "unfinished separations' within a text" (Blanchot 1986: 86)? And if so, will the reader find the true answer for the text's immanent questions? Or does the reader rather run the risk of losing himself in the never ending fragmentation of the original text that only seems to develop towards completion during the reading process; a process that in reality actually "digresses, dissipates, dissolves, disappears" (Mellamphy 1998: 84), yet transcends into a new fragment of nothingness? In other words, are Blanchot's texts so fragmented that the reader will never be able to overcome this breakdown of communication between the text and the reader; a breakdown that is representative of the death of communication and its resulting silence? 


\section{"I will not tell you everything": The Silent Articulation of Something Other}

It cannot be denied that Blanchot's "unfinished separations" (Blanchot 1986: 86) create silence between fictional characters as well as between text and reader. However, it is only through the engagement with the (un)spoken or (un)written word that the character and the reader realize that this particular silence allows for self-questioning and self-discovery, which ultimately leads to the true meaning of the work: a better and deeper understanding of one self that results from a deep reflection on the written text. This said, Awaiting Oblivion seems to hold the key to all the questions raised above, even though the work itself allows neither its characters nor its readers to understand fully the situation and the relationships depicted. Yet, it is not the plot of the story that is of primary importance, but the active engagement with the text that allows for the development of a new form of awareness and self-consciousness through constant reflection on the textual product and the self. As a result, Blanchot's texts say nothing at first sight, but express actually everything upon reflection.

This argument finds support when looking closely at the statement: "I will not tell you everything" (Blanchot 1997: 11); a statement that indicates resistance and repression. The sentence functions as a selective vocalization of something that has not yet and never will be precisely defined. As such, the sentence utters the silent articulation of something other, something that, according to Anne McConnell, takes the characters' and readers' focus "away from the words and the narrative itself as the locus of truth, provoking [both] to search elsewhere" (2013: 175). This can only entail looking for meaning outside of the actual text and its immediate surrounding and to take Blanchot's work for what it is: a literary manifestation of Levinas's face of the other that looks at me, speaks to me, and imposes itself on me. It is the face of the other to which I, the reading subject, am drawn. Since my engagement with the other, in this case Blanchot's textual surface, "is not attached to a particular feature of this other but to [its] entrance into my world, all others oblige me as much as this one" (Peperzak 1993: 31). This means that this other, as already stated, cannot be reduced to one singular entity or, in our case one singular text, but should rather be understood as something that can have multiple forms and that may transcend physical existence.

Searching for the textual implications outside of the text then forces us, the readers, "to wait outside our own waiting, leaving us nothing more to await" (Blanchot 1997: 14) than ourselves. When this point is reached and the reader realizes that the text cannot answer the questions it triggers, the generated other becomes internalized, because it then points towards me, the internal object to which the self or the speaking subject-I-is inevitably linked (Reuber 2014). On the one hand, it becomes an expression of negation of the textual external other. On the other hand, it has to be perceived as an affirmation of the self, the psychological entity that is constructed of the I-the speaking subject-and me-the object-the internal other expressing in its own incomprehensible language the needs, desires, hopes, fears, etc. that affirm singularity and authenticity of the self. The text's imposed demand on the readers to act becomes the readers' enactment 
of their own desires to react. Hence, it is only through the interaction with the external other that the internal other contests the state of being, simply because it demands a reevaluation of "both self and the totality of other things" (Benjamin 1997: 17). This leads to the conclusion that only via the engagement with the other we learn "what we cannot learn from ourselves [alone] and develop a better understanding of both the other and the self" (Waldenfels 2008: 68).

Therefore, whether the object is external or internal, it is inevitably linked to the subject, which defines itself through "its relationship with the object" (Scharff 1992: 23). It is this link that fosters "the comprehension of who "we" are" (Hewson 2011: 19) and, consequently, of who we become. In other words, the self is "related and linked to the other from which it is separated," but from which "it is unable to escape" (Peperzak 1993: 53), whether the other is internal or external.

Maurice Blanchot illustrates this inextricable relationship between the self and other through the interplay between characters, their interaction with each other, and the breakdown of communication and human relationships. In this sense, he expresses the opposition between the self and the external other-youwhose relationship with one another is expressed and practiced through language. He further exemplifies this relationship via the absence of speech and the acknowledgement of the innermost thoughts that shall not be uttered and recognized, but rather repressed. Blanchot's characters are ruled by their non-recognition of the dynamic relationship consisting between the subject-Iand the object-you and me-the exterior and interior other that opposes and challenges the self.

Whether confronting the exterior or interior other in a social setting or in a one-on-one conversation, the reaction to the unknown opposing and imposing on the self is fear. It is the fear of the other that lays claims on to the self and, by doing so, challenges one's self-conception to the extent that the other seems to dominate the self and eliminate the one thing one once thought to know (Critchley 1996). It is the fear of a violent change that is imposed onto the speaking subject via the destructive function of language. As Ullrich Haase and William Large point out in their monograph on Maurice Blanchot, "the other approaches me in speech as the stranger and as the unknown, who comes to me from outside [or inside] and who, in addressing me, undermines my self-repose and certainty" (2001: 76).

Speech in this sense needs to be understood as a verbal and visual way of communication to which the self responds in either a verbal, visual, or tactile way. This interchange between self and other is constant and serves as a reminder of invasion of personal space, as well as a reminder of reality that everything belongs to both of us, you and me. As a consequence, reality "becomes genuinely 'exterior'-and at the same time, I become genuinely 'interior,' because I am now truly differentiated from the external world" (Young 2016: 2). This insight leads to the realization that I myself am other, other to you as well as to what I thought constituted my own self, because the "I" is far from being complete; it is transcendental, thus, constantly developing and becoming something other.

From this insight follows that "I am related to many others who urge me with equal absoluteness to dedicate myself to them" (Peperzak 1993: 168), who hold 
me responsible for them, and who challenge the notion of who I think I am. Confused and fearful, I retrieve from the other socially, emotionally, and also verbally, because-using now the narrator's words from Awaiting Oblivion "[w]hen I speak to you, it is as if the entire part of me that covers and protects me abandoned me and left me exposed and very vulnerable" (Blanchot 1997: 10).

Consequently, not everything can or should be expressed, but rather remain unarticulated, suppressed, and held back. This kind of negation and suppression leads, of course, to yet another breakdown of communication. Silence and solitude are again its subsequent results. However, this self-imposed restraint also allows the writer to produce "meaningful prose" (Blanchot 1986: 332), because through saying nothing, the writer, reader, speaker, and listener are able to preserve the distance between themselves and the other and to maintain singularity and authenticity of thought and being. Only then is there no risk of "reducing that which is named to the level of banality" (Kleinberg 2005: 217) or imposing one's self onto the other or vice versa.

Nevertheless, the phrase "I will not tell you everything" (Blanchot 1997: 11) also expresses the opposite, namely that something will be revealed. As a result, the statement creates the sense of hesitation and waiting; a waiting for clarification, for resolution, for everything "what is outside" (Blanchot 1993: 304) of our knowledge, for everything that belongs to the silently implied unknown. Therefore, the sentence "I will not tell you everything" (Blanchot 1997: 11) addresses the lack of the understanding of le tout. It alludes to "what is still to be attained and of what is still to be known" (Blanchot 1997: 11). It addresses an everlasting waiting that is "interminable and inescapable, without culmination nor redemption" (Hill 2012: 131), a waiting that becomes an experience itself.

In my understanding of Blanchot, the statement silently pronounces an act of waiting for the understanding of one's self in relation to the other at the same time that it negates an existing ideal or absolute form of being. ${ }^{4}$ Even though this statement applies to all three of Blanchot's novellas discussed in this article, the act of waiting and the negation of an existing ideal manifests itself differently in each one of them.

In his novella Death Sentence, waiting is manifold: Whereas J. awaits alleviation of pain through death, the anonymous narrator seems to await the extinction of the female other, in order to find his voice to tell his story. It seems that the narrator's sudden act of enunciation results from his processing of J.'s severe illness and subsequent death, thus, through the waiting for the passing of the other. In Awaiting Oblivion, the narrator's waiting for the understanding of his self in relation to the other expresses itself in the unsuccessful act of communication that is characterized by long lists of unanswered questions creating a void between the interlocutors. This waiting for deeper knowledge is though brutally withdrawn from the text when stating: "I will tell you almost nothing" (Blanchot 1997: 11). These words invalidate everything that the character and the

\footnotetext{
${ }^{4}$ This is similar to Hegel's notion of absolute idealism according to which, "only mental entities are real [...] [and] physical things exist only in the sense that they are perceived" (www.philosophypa ges.com/dy/i.htm\#idlm). In other words, only mind and spirit represent the ultimate reality and form of being.
} 
reader once awaited, namely the possible understanding of the other and the understanding of me in relation to you. In addition, it leads to the painful awareness that we are, as Blanchot says, "waiting for ourselves without ourselves, [...], leaving us nothing to await" (Blanchot 1997: 14). In other words, we are kept prisoner in a never-ending and unsuccessful process of waiting to ever understand ourselves as well as our relation to the other. This then leads to the realization that we are left in a vast void in which we are separated by everything that we do not want to articulate (Blanchot 1997: 20).

This void and "solitary waiting" (Blanchot 1997: 14) for and through the other is nowhere better expressed than in The Madness of the Day, a story whose male narrator reflects upon identity, activism, resistance, and otherness. Statements such as "In haste, I would rid myself of myself. [...] I reduced myself to them. [...] [and] I'm a special case. Special if you act-never, if you let others act" (Blanchot 1981: 14-15) articulate clearly the interconnectedness of the self and the other. In addition, these statements oppose the absolute form of being and point towards the respective notion of self-determination and identification through the other. The fact, however, that Blanchot's narrator ends his account refusing to ever tell another story implies that he favors silence over communication and distance from over closeness to the other. Since the self only develops through the interaction with the other, his statement-"No stories, never again" (Blanchot 1981: 18)indirectly implies the narrator's lack or negation of self-consciousness.

\section{Confinement to and Recitation of Otherness}

This resulting insufficient understanding of the self is at the heart of all three of Blanchot's texts. In all three novellas, his desubjectivized narrators are incapable of providing either a complete portrayal of themselves or of the situations they seek to resolve. Characters and narrator seem to be "stuck in living spaces-houses, apartments, infernal institutions, [and] hotel rooms" (Kaufmann 2005: 126) that are sparsely furnished. Whether in J.'s sickroom in Death Sentence, the narrator's cold and modest hotel room in Awaiting Oblivion, or the narrator's unidentified institution in The Madness of the Day, the stories' characters all relive similar situations, which are characterized by a lack of detail, a lack of communication, and, most importantly, a lack of understanding of the situation, of the other, as well as of themselves. In The Madness of the Day, this lack of detail and absence of comprehension expresses itself in the articulation of non-coherent paragraphs ranging from the depiction of the narrator's education, to his travels, love-life, trials, constant affirmation of being asleep, to a range of questions such as: "I asked myself, wasn't I sad, hadn't I felt my life breaking up?", What was I before?", "Who am I? ", "Who was answering?" (Blanchot 1981: $7,8,10,17)$.

These questions remind the reader of the incoherent dialogue of the man and woman in the hotel room in Awaiting Oblivion. Here the text opens with "Who is speaking?" (Blanchot 1997: 1), followed by "Why do you listen to me as you do?", "Why do you attract in me these words that I must then say?" or "What could I do?" (Blanchot 1997: 4, 7). As in The Madness of the Day, characters in Awaiting 
Oblivion do not find answers to these questions within the text. They are left waiting and wondering about "the meaning of this whole story" (Blanchot 1997: 11), and engage in negative discourse, which seems as silent and empty as the text itself.

In this sense, narrator and fictional characters mirror Blanchot's defective writing and become confined to the space of textual otherness that they are unable to leave (Blanchot 1997: 13). However, it is within this confinement that text and characters engage in Blanchot's double parole and pronounce everything and nothing that they always wanted to say. As mere placeholders for the face of the other, narrator, character, and textual surface put forth a discourse whose message Blanchot re-cites ${ }^{5}$ in all three novellas, namely: "I will tell you almost nothing" (Blanchot 1997: 11). It is a message that exemplifies the quintessence of the author's understanding of the textual artifact as a representation of the Levinasian face of the other, namely that "we are concerned with saying, not with the said" (Waldenfels 2008: 68).

With this in mind, the reader stops searching for detailed information about any of Blanchot's fictional characters. In Death Sentence, it seems irrelevant to know what J. was suffering from or why she was longing for the beginning or end of dying. In Waiting for Oblivion, it is unimportant to understand the relationship between the anonymous narrator and his female counterpart at the hotel. In Madness of the Day, it is no longer necessary to comprehend what triggered the narrator's acute but distorted perception of his surrounding that "assailed [him] irrationally, without control, without purpose" (Blanchot 1981: 11) and that allowed even the light of the day seem to go mad.

What is important is the realization that the breakdown of understanding of the textual other not only closes but, at the same time, instigates "the resurrection, or the starting over, or the living beyond the life of the narrative" (McConnell 2013: 196). It (re)opens the récit through its re-telling. In other words, it allows the breakdown of understanding to arise "out of the excessive space that precedes it" (McConnell 2013: 197) and to continue in the repetitive attempts to make one's self understood through a highly fragmented and elliptic discourse. This realization exemplifies "the power of language to negate the immediacy of things" (Haase and Large 2001: 31) on the one hand, and the consequential never-ending expression of ideas, on the other.

It is this present absence or absent presence of language that negates any "extra-linguistic reality" (Haase and Large 2001: 31) and produces self-questioning. Consequently, it exemplifies that "the search for the truth is not uniquely a discovery of the exterior but a transcendence or [...] a 'transcendence' toward a dimension that commands us" (Peperzak 1993: 43). As such, Blanchot's work allows for l'expérience-limite to occur: an experience that defines a complex relation "that man encounters when he has decided to put himself radically in

\footnotetext{
${ }^{5}$ The etymological meaning of the verb "to recite" derives from the old French verb réciter which is a derivative of the Latin verb recitare meaning "read aloud, read out, repeat from memory, declaim," Online Etymological Dictionary (http://www.etymonline.com/index.php)?allowed_ in_frame $=0 \&$ search=recite\&searchmode=none $>$. The verbs suffix "re" indicates a repetitive action, a re-telling, re-summoning of something.
} 
question" (Blanchot 1993: 203). This relation has to be understood as an opportunity to experience authenticity and singularity on the physical, psychological, emotional, and cognitive level via one's engagement with the other through language: provided that one understands that the discourse with the other does "not reveal anything, because everything [has] long since been revealed" (Blanchot 1981: 17). Consequently, the statement: "I will tell you almost nothing" (Blanchot 1997: 11).

The antithetical statement, "I will tell you almost everything; I will tell you almost nothing" (Blanchot 1997: 11) then illustrates well the double parole of Blanchot's work. It is a parole that expresses the necessity but also the insufficiency of the spoken and written word to help define the self in relation to the internal and external other. It is a parole that "has linked the presence of negation to affirmation" (Benjamin 1997: 18) of speech and being, as well as to the recognition and negation of "the precise, balanced speech of man" (Marshall 1986: 226) whose notion of selfhood will never be fully known but will always remain in the making.

\section{Exploration and Understanding of the Self and the other via the Neutrality of Language}

This notion of the unknown, of the state of self-unawareness, and of the lack of self-consciousness, manifests itself also in the use of subject pronouns in the work. The ease with which the narrative voice in the three novellas substitutes or interchanges the first-person subject pronoun je with the third-person subject pronoun $i l$ or elle as well as with the first-person plural subject pronoun nous supports the argument previously made, namely that the narrative voice is desubjectivized and unable to speak for him/herself.

It can even be argued that if je can be substituted by nous as is predominantly the case in Awaiting Oblivion, the self is no longer different from the other, resulting first in the absorption of the other, second, the consequential objectidentification with the other, and third, the ultimate transformation of the self into the other and vice versa. This implies that the text no longer shows a real dialogue between the individual interlocutors (Blanchot 1997: 25), but rather conflates voices until one voice substitutes the other. The result is the complete loss of identity, on the one hand, and the gain of anonymity, on the other. As my subjectivity becomes "interrupted by the alterity" (Sealey 2013: 435) of the text and its desubjectivized voice, my message becomes your message and one is no longer able to distinguish between who is being asked and who is asking. As roles between self and other then become interchangeable, the message loses its singularity and becomes an expression of either everything or nothing, combining the different voices initially heard into a single one: our message. It is then that the two entities become one, or as Blanchot says: "the one is the other" (1997: 26).

In Blanchot's texts, this particular message turns into an utterance of fragments which eventually results in what Manola Antonioli calls "la discontinuité absolue des blancs des pages" (1999: 33). This discontinuity leads to the textual 
representation of a narrator who is incapable of establishing himself "comme narrateur et sujet de son proper récit" (Antonioli 1999: 39). Consequently, the first-person narrator in question becomes a narrator who, like the text itself, appears fragmented, incoherent, and lost in the overall "impersonality of the work" (McConnell 2013: 26). This dissolution of identity and singularity finds its pendant in the sparsely furnished bedrooms or hotel rooms, whose predominant characteristic is emptiness even when "full of strangers" (Blanchot 1978: 18).

The fact that the narrator in Death Sentence declares that "everything about that room, plunged in the most profound darkness, was familiar to [him]" and that even though empty that room held "the most intense life" (Blanchot 1978: 67) illustrates the coexistence of absence and presence, of silence and noise, of emptiness and fullness. More so, it expresses the coexistence of the speaking subject-I-and the listening object-me-within the room of existence. As such, these words exemplify the "very divide between the interiority of the self and exteriority" (Sealey 2013: 437), the divide between the self and the other as well as the time in between being and becoming.

It is in "these close quarters, where the words she said could signify nothing other than this confinement" (Blanchot 1997: 13), and where the exploration, assimilation, and exchange of the self and the other takes place, allowing the character and narrator to disappear and the reader to enter the work. It is in this place, where the non-identified female character in Awaiting Oblivion asks her male counterpart, "Do you want to separate yourself from me? But how will you go about it? Where will you go?" (Blanchot 1997: 13-14). Like so many other questions before, these remain unanswered, leaving the voices of the characters "ring out in the immense emptiness" (Blanchot 1997: 7) of the empty place.

But why is it that the interlocutor chooses one more time silence as a response? The answer to this question is twofold. First, whereas earlier the other transferred the responsibility to find answers to the questions onto the reader out of convenience, thereby commanding the reader to complete the literary text while assuming the role of the speaking subject, now the silence of the male narrator is rather symptomatic of his lack of self-knowledge and selfawareness, as well as his shortcomings in understanding the other in relation to the self. The narrator in Awaiting Oblivion simply does not know the answers to the questions asked by his female interlocutor. Moreover, he is not even aware that he is alone in the hotel room, and that the two different voices heard actually both belong to him, "the male lead, also a writer, and a woman, the mysterious, unknowable, unseizable figure of the dehors, the outside" (Gregg 1997: xi), the narrator's unrecognizable other.

Second, whether resulting out of convenience or an illustration of an insufficiently developed understanding of the self, the occurring silence also functions as a negation of the other. As such, the unanswered questions serve as a means of attestation and preservation of selfhood. It is Blanchot's double parole at its finest; a parole that is not only a speech of absence or silence, but also a non-verbal (silent) reference to the non-existence of an absolute being on the one hand, and an affirmation of "a conception of singularity that is linked to authenticity" (Benjamin 1997: 13), on the other. It becomes obvious that at a 
time where speech expresses itself in silence and negates the other, the oral speech or the written text reveals something "that is beyond reach (of the one who says it as much as the one who hears it) " (Blanchot 1993: 212). It is something "that Blanchot calls the 'relation to the unknown' and that finds expression in the silence of speech" (Haase and Large 2001: 76). As such, it is something that allows for the "always eternally becoming" (Mellamphy, 1998: 85) of being that is far from its ideal or absolute form, but which, at the same time, is always part of the one thing that becomes, our self.

Without a definite and absolute being, there is no definite or absolute speech, thus, there is neither absolute truth nor lie attached to what is said. From this we can conclude that our speech is nothing else than "an undecided movement between what [we] cannot possibly do and what [we] can't help doing" (Smock 1999: 1041), namely expressing our thoughts and forcing them onto the other. It necessarily follows that Blanchot's double parole is a speech of silent and powerful possession that even though not uttered loudly, represents a loud cry from within; a cry that runs through all three works and that seems to be uttered by "the mouth of someone [the narrator] did not know" (Blanchot 1978: 28). It is a cry that, over time, takes on such a fragmented and regressed form that it is too difficult to be understood by oneself or by the outside world. It is a cry that we as readers have to set in relation to our own self, as it is and always will be "subjected to and unable to escape from me being regarded, touched, and disposed of by my encounters" (Peperzak 1993: 28-29) with the other.

As a consequence, the characters in Blanchot's texts seem to remain silent, "with nothing left to say, [and] the work ultimately becomes the speech of itself" (Marshall 1986: 227). It becomes the testimony of otherness expressing itself in the form of questions that are only answered through the reading process of the récit. Hence, as the narrator in Death Sentence states: "What is extraordinary begins at the moment I stop" (Blanchot 1978: 53). But what begins at the moment the narrator stops narrating? What is hiding behind the face of the other, Blanchot's story that is nothing else than the event that it tells and re-tells?

It is the intrusive presence of what Emmanuel Levinas calls the il y a: "the anonymous and impersonal current of being" (Kleinberg 2005: 218) in which the everyday world dissolves, disappears, and becomes. It is an entity of no specific form or clarity, an allusive and infinite neutral existence "divorced from the principle of individuation" (Large 2002: 136) that lurks around like an everlasting shadow invading and disarming the self by the simple fact that there is. As such, Levinas's il y a "constitutes a lack or deficiency of the presence of being" at the same time that it represents a "justification for seeking a beyond of being" (Bautista 2012: iv).

In regard to Blanchot's writing, the notion of the il y a then hides behind the voice of the desubjectivized narrator and the non-identifiable characters. It expresses itself through the works' negative discourse that is characterized by an adhesive string of words or ideas representing a fragmented picture of a whole; something that strives for completion via the "neutrality of language" (Haase and Large 2001: 80). It is an indefinable force that hides behind the face of the other and that puts the self into question, forces it to reflect, to evaluate, and to assess its 
current form of being and, consequently, its becoming. Hence, the existing entity of the il y a challenges one's identity via its body, face, and language.

When not being able to define this "obscure invasiveness against which there is neither refuge nor recourse" (Toumayan 2004: 151), the narrator of Death Sentence for example reacts with terror and refers to the il y $a$ as something that "I am no longer able to speak of" (Blanchot 1978: 30). He describes it as something whose infinite character cannot be expressed via the limited set of words simply because the il y a designates "the time of a "between," the no longer and the not yet" (Sealey 2013: 437). This in-between state of what once was and what will be finds exemplification in J.'s continuous suffering and fight for her life, on the one hand, and the narrator's respective fight for the right words to convey to the reader his perception of the situation, on the other. J.'s physical and the narrator's intellectual suffering, then go hand in hand, yet even have the same outcome. J. dies, and the narrator turns silent after informing the reader: "I don't want to say anything. [...] I am no longer able to speak of it" (Blanchot 1978: 30). "It" referring to the il y $a$, then has to be understood as an indefinable absent presence as well as a present absence. It is something that is intricately linked to Blanchot's defective ré-cit.

While hiding behind the face of the other-Blanchot's textual artifact-the presence of the Levinasian il y $a$ is symbolic for "a temporality of incessant return rather than to one defined in terms of an absolute beginning and end" (Gregg 1994: 29). It is the readers' constant reminder of the never-ending text, ensuring an everlasting waiting and "quest for the work" (Blanchot 2003: 200) as well as for a complete understanding of the self. As long as the reader is not able to fully understand him-/herself or is incapable of finding him-/herself "as a self with power" (Sealey 2013: 436), the il y a remains an ever-present oppressive force that cannot be explained. Hence the exclamation: "I am no longer able to speak of it" (Blanchot 1978: 30). Repressed in thought, the il y a remains unarticulated, but present. It hides behind the narrator's filled void, behind his fragmented speech, the face of the other. Hence, the il y a closes and reopens Blanchot's récits and maintains the quest for the true understanding of the self, which is no longer the same, but not yet redefined and fully understood. It is the double parole of Blanchot's texts, which allows for the discovery of the hidden message of the writer's seemingly void text: the silent but violent cry for reconciliation of the self and the other, of being and becoming.

\section{Conclusion}

In conclusion we can state that this silent cry for reconciliation of self and other, of being and becoming, runs through all three of Blanchot's novellas discussed in this article. It is a cry that results from the otherness and strangeness of the literary work manifesting itself in its fragmented structure, lack of visualization and detail, and a seemingly empty discourse between the fictional characters and a desubjectivized narrator. This cry is representative of Blanchot's understanding of the incompleteness of the written document and the resulting 
quest for the work on the one hand, and the quest for a better and deeper understanding of the self and of the other.

As illustrated throughout the analysis, this quest starts with the reading process demanding the reader's constant engagement with the text. However, this quest actually continuous beyond the textual boarders due to the fact that the fragmented text triggers an endless number of questions without ever answering them. As a result, the written artifact imposes itself onto the reader and demands completion of the text through the reading process. By doing so, it challenges the reader to reflect on the text, but also on his/her perceptions and viewpoints throughout the reading process. Through constant reflection on the textual artifact, the reader engages not only with the written word, but more importantly, with the questions it triggers leading to the understanding that not what was said is of importance, but that something was said, something that the reader needs to reflect on and process. It is then the space that results from what was said and the imposition that results from it that challenges the reader's understanding of self. As such, Blanchot's texts take the form of the unidentifiable Levinasian face of the other behind which is and hides something; something that commands us, readers, to command and to take action, to seek self-awareness, to develop selfconsciousness, and to take the role of the other, the speaking text.

\section{References}

Antonioli M (1999) L'Ecriture de Maurice Blanchot. Fiction et Théorie (The Scripture of Maurice Blanchot. Fiction and Theory). Paris: Editions Kimé.

Bautista St. (2012) Ontology in Emmanuel Levinas's Philosophy. Unpublished doctoral dissertation, Loyola University of Chicago. Retrieved from https://bit.ly/2mneT4g. [Accessed 10 June 2016].

Benjamin A (1997) Figuring Self-identity: Blanchot's Bataille. In J Steyn (Eds.), Other than Identity. The Subject, Politics, and Art, pp. 9-31. Manchester and New York: Manchester University Press.

Blanchot M (1978) L'Arrête de mort (Death Sentence). Translated by L Davis. New York: Station Hill Press.

Blanchot M (1981) La folie du jour (Madness of the Day). Translated by L Davis. Barrytown, NY: Station Hill Press.

Blanchot M (1986) L'écriture du désastre (The Writing of disaster). Translated by A Smock. Lincoln: University of Nebraska Press.

Blanchot M (1993) L'Entretien infini (The Infinite Conversation). Translated by $\mathrm{S}$ Hanson. Minneapolis: University of Minnesota Press.

Blanchot M (1995) La Part du feu (The work of fire). Translated by C Mandell. California: Stanford University Press.

Blanchot M (1997) L'Attente l'oubli (Awaiting oblivion). Translated by J Gregg. London: University of Nebraska Press.

Blanchot M (2003) Le Livre à venir (The book to come). Translated by C Mandell. California: Stanford University Press.

Critchley S (1996) Il y a-Holding Levina's hand to Blanchot's fire. In C Bailey Gill (Eds.), Maurice Blancho: the Demand of Writing, pp. 108-122. New York: Routledge.

Davies P (1996) The work and the absence of the work. In C Bailey Gill (Eds.), Maurice Blancho: the Demand of Writing, pp. 91-107. New York: Routledge. 
Gregg J (1994) Maurice Blanchot and the literature of transgression. New Jersey: Princeton University Press.

Gregg J (1997) Introduction. L'Attente l'oubli (Awaiting oblivion), pp. vii-xvii. Translated by J Gregg. Lincoln and London: University of Nebraska Press.

Haase U, Large W (2001) Maurice Blanchot. London and New York: Routledge.

Hewson M (2011) Blanchot and literary criticism. New York: Continuum International Publishing Group.

Hill L (2012) Maurice Blanchot and fragmentary writing. a change of epoch. New York: Continuum International Publishing Group.

Kaufmann E (2005) Midnight, or the intertia of being. In L Hill, B Nelson, DD Vardoulakis (Eds.), After Blanchot: Literature, Criticism, Philosophy, pp. 123-136. Newark: University of Delaware Press.

Khatab R (2005) Timelessness and negativity in Awaiting Oblivion: Hegel and Blanchot in Dialogue. Colloquy 10: 83-101.

Kleinberg E (2005) Generation existential. Heidegger's philosophy in France 1927-1961. Ithaca: Cornell University Press.

Large W (2002) Impersonal existence. A conceptual genealogy of the "There Is" from Heidegger to Blanchot and Levinas. Angelaki. Journal of the Theoretical Humanities 7(3): 131-142.

Levinas E (1987) Collected Philosophical Papers. Translated by A Lingis. The Hague: Martinus Nijhoff.

Llewelyn J (2008) Levinas and language. In S Critchley, R Bernasconi (Eds.), The Companion to Levinas, pp. 119-138. Cambridge, UK: Cambridge University Press.

Marshall DG (1986) The necessity of writing death and imagination in Maurice Blanchot's L'Espace Littéraire. Boundary 2(14): 225-236.

McConnell A (2013) Approaching disappearance. London: Dalkey Archive Press.

Mellamphy D (1998) Fragmentality (thinking the fragment). Dalhousie French Studies 45: 83-98.

Peperzak A (1993) To the Other. An Introduction to the Philosophy of Emmanuel Levinas. Indiana: Purdue University Press.

Reuber A (2014) In Search of the Lost Object in a Bad Place: Stephen King's Contemporary Gothic. In P Simpson, P McAleer (Eds.), Stephen King's Contemporary Classics. Reflections on the Modern Master of Horror, pp. 101-116. Lanham, MD: Rowman \& Littlefield.

Scharff DE (1992) Refinding the object and reclaiming the self. New Jersey: Jason Aronson Inc.

Sealey K (2013) The "Face" of the Il y a: Levinas and Blanchot on impersonal existence. Continental Philosophy Review 46(3): 431-448.

Smock A (1999) Tongue-tied Blanchot, Melville, des Forêts. Modern Language Notes 114(5-Comparative Literature Issue): 1037-1061.

Thomas EL (2004) Emmanuel Levinas: ethics, justice, and the human beyond being. New York and London: Routledge.

Toumayan A (2004) Encountering the Other. The Artwork and the Problem of Difference in Blanchot and Levinas. Pittsburgh, Duquesne University Press.

Young B (2016) An Introduction to Levinas. Retrieved from https://bit.ly/2kwlyaQ. [Accessed 15 December 2016].

Young B (2017) Meaning of "The Face of the Other". In The Face of the Other. Retrieved from https://bit.ly/2moYFrn. [Accessed 15 December 2016]. 
Waldenfels B (2008) Levinas and the face of the other. In S Critchley, R Bernasconi (Eds.), The Cambridge Companion to Levinas, pp. 63-81. Cambridge, UK: Cambridge University Press.

Wellbery DE (1996) Exercises on The Madness of the Day. Proper Names. Translated by MB Smith. California: Stanford University Press. 



\title{
Metaphorical Euphemisms in the Original Text and Italian Translations of F.M. Dostoevskij's Novel Crime and Punishment
}

\author{
By Aleksandra Burkhailo*
}

\begin{abstract}
The following paper deals with the euphemisms occurring in the original text and some Italian translations of F.M. Dostoevskij's novel "Crime and Punishment." Particular attention is given to the euphemisms formed via application of metaphor, as it appears to be one of the most effective veiling instruments. First of all, the main thematic areas of metaphorical euphemisms use are indicated and, subsequently, a lexicographic-cultural analysis is conducted paying attention, as well, to the essential functions and processes of formation of such a type of words and expressions in Russian and Italian. An important part of the article is devoted to the contrastive analysis of Russian metaphorical euphemisms found in the text of the novel and their translations into Italian. Apart from the masking meaning, metaphorical euphemisms contain those cultural and symbolic, expressed by means of semiotic content of denotatum, and this characteristic makes of them often a complicated translation problem to resolve. Some examples will be delivered in order to demonstrate the major tendencies translators follow dealing with the issue.
\end{abstract}

Keywords: Euphemism, Indirect nomination, Metaphor, Metaphorical euphemisms, Translation of euphemisms

\section{Introduction}

Humans combine biological and social characteristics. The second ones make of us a society, such a huge community, so difficult to be organized. Language is an essential mean for social interactions and the inner organization of our community. In the society there are written and unwritten laws that regulate life inside it. Both of them have the form of language signs. The laws presume following particular patterns of behavior in a given situation. A crucial role in these patterns is assumed by linguistic behavior. Then, the reflections on how to act go always together with those on what to say.

The social co-existence makes us think a lot of our interlocutors and the effect of what we say. Therefore, sometimes we are sure we can say things the way they are, following the line of direct nomination. Although it is obvious we have restrictions, as well, and they are not a few. As Wardhaugh puts it: "No one speaks the same way all the time and people constantly exploit the nuances of the languages they speak for a wide variety of purposes" (Wardhaugh 2006: 5). There are a lot of social and cultural factors and conditions limiting our linguistic behavior and making us employ indirect nomination, or substituting offensive or harsh words by those more neutral and pleasantly sounding (Katsev 1987: 64). Such words are called euphemisms.

*PhD Student, University of Naples "L'Orientale", Italy. 
Most scientists claim that euphemisms have their origin in the phenomenon of taboo, its linguistic aspect, which presumes some words to be interdicted. During the earlier periods of our history, such words were names of gods, in some cultures, names of ordinary persons or dead, wild animals which were objects of hunt. During the Medieval period a lot of words from religious field were often interdicted and those relating to pestilences, as well. So, the euphemisms of those periods were principally conditioned by superstitious fears.

As for the Modern Age, euphemisms generating factors have completely changed: numerous etiquettical euphemisms have appeared and continue to appear, as for us, nowadays, in the period of active globalization process, it is essential not to sound offensive, especially when it comes to international contacts, which require, as well, adequate interpretation from language to language.

Euphemisms often represent a difficult translation problem to resolve, as they can have the form of both words and expressions, they always have a cultural element in the meaning and can be formed by means of different tropes. One of the most effective veiling instruments and, as a result, one of the most effective euphemistic meaning basis is metaphor, thanks to its figurativeness which distracts our attention from an interdicted object or phenomenon.

The main purpose of the research is to analyze the way translators deal with Russian metaphorical euphemisms interpreting them into Italian. For such an aim a comparative analysis of the euphemisms taken from the original text and seven Italian translations of F.M. Dostoevskij's novel Crime and punishment will be carried out. We will focus, as well, on conducting a lexicographic-cultural analysis of the found lexical units paying particular attention to the principles of formation of metaphorical euphemisms in Russian and Italian and to the metaphorical concepts which are used to create euphemistic meaning basis in both languages. Finally, the main functions and fields of metaphorical euphe-misms use in the novel will be indicated.

\section{Literature Review}

Scientific interest to euphemisms has manifested not before the XX century, and has been marked by a series of papers devoted to euphemisms, their semantic characteristics in different languages. For instance, O Eufemismo e o Disfemismo na Língua e na Literatura Portuguesa by João da Silva Correia (1927), O Eufemismo e o disfemismo no português moderno by Heinz Kröll (1984) for Portuguese, Le brutte parole, Semantica dell'eufemismo di Nora Galli de' Paratesi (1969) for Italian. As for the English language, it became to a great extent object of lexicographic description, the most well-known results of which are $A$ Dictionary of Euphemisms \& Other Doubletalk by Hugh Rawson (1981), How Not to Say What You Mean - A Dictionary of Euphemisms by R. W. Holder (2002).

In the Russian scholar one of the fundamental works devoted to euphemisms was created by A.M. Katsev and entitled Jazykovoje tabu i evfemija (1988). The monograph provides the reader with a panoramic view on the process of the phenomenon of euphemism development: from the ancient taboo to the 
contemporary euphemistic use. The description is enriched with examples from different languages. Another essential emphasis is done to the description of euphemism's nature. One of the most important characteristics is that it consists of three elements: social, psychological and linguistic. The first one considers social, religious, moral and other reasons that condemn direct nomination, the second relates to the negative emotion we experience when pronounce or hear an interdicted word or expression, and the third one is divided into two elements: negative denotatum of the interdicted word and the ameliorative effect of an employed euphemism (Katsev 1988: 5). This scheme demonstrates complicity and interdisciplinarity of the phenomenon.

Another important Russian researcher is V.P. Moskvin who published a monograph Evfemizmy v leksicheskoj sisteme russkogo jazyka (2017) which is another work referred to the general theory of euphemia with particular attention to the methods of their formation and the fields of use, as well as, to some similar phenomena euphemia should be distinguished from. Apart from this, Moskvin elaborated a thematic-functional classification of euphemisms, which we partly applied in the paper.

Slovar' evfemismov russkogo jazyka by E.P. Seničkina (2008) is the first experience of lexicographic line in the studies on euphemisms.

\section{Methodology}

The research was started with choosing a Russian text. The author and the novel were not selected by chance. We needed a reliable classical text which addresses issues requiring euphemisms. Besides, it had to be culturally representtative, difficult to be translated. Another important point is that Dostoevskij is considered one of the Russian writers who more frequently than others employed euphemistic style (Moskvin 2017: 64). And, finally, Dostoevskij is an extremely popular writer in Italy, and it provoked and continues to provoke creating numerous translations of his texts. Very few Russian writers were translated so many times, so it gives a good possibility for comparative research.

The next step was to work with the Russian text individualizing euphemistic uses and to create a corpus. Subsequently, it was time to find some Italian translations. For the present paper we worked with seven translations.

We carried out two types of analysis: lexicographic-cultural and translational. The first presumes semantic inquiry, with particular attention to the concepts used to create euphemistic meanings in both languages, consulting a number of dictionaries. Besides, it includes the lexical characteristics of euphemisms permitting them to have, to increase or to decrease veiling effect.

The second type of analysis, which consists in a comparative inquiry of the translations, allowed us to observe the tendencies followed by translators interpreting Russian metaphorical euphemisms into Italian. 


\section{Results}

The conducted research allowed us to individualize three mostly frequent thematic areas requiring metaphorical euphemisms in the novel, and they are death, alcohol consumption and its consequences and mental abilities. Some examples of Russian metaphorical euphemisms from each field and of their interpretations into Italian will be delivered and analyzed below.

\section{Death}

Death is a traditional frightening phenomenon in various cultures, and as a consequence, a reach source for creation of euphemisms. Even the less superstitious persons often use euphemisms talking about death and other frightening things. Moskvin considers such euphemisms to be one of the groups in his thematic-functional classification: Frightening phenomena as object of euphemization [Pugàjušjije javlènija kak objekt evfemizàtsii] (Moskvin 2017: 102).

\section{Pokojnyj [Peaceful]}

In the original text of the novel the most frequently observed euphemism for dead is pokojnyj [adjective from pokoj - peace] or pokojnik [noun from pokojpeace]. The adjective often becomes a noun for the process of conversion. It is principally used in juridical and other formal contexts.

The metaphoric concept of peace, substituting that of death, results in extenuation and reducing the negative effect produced by the argument, and in this way the denotatum is ameliorated and the euphemistic base is created.

A completely positive vision of death is observed, thanks to the metaphor, so the euphemism is curious to be analyzed from the cultural point of view as well. As the dictionary of the Russian language reports (Evgenjeva 1999), the word pokojnyj has five meanings, and that regarded to death was the latest to form. The metaphor, the meaning was created with, may be referred, first of all, to the physical state of a dead person, as he or she is not able to move anymore, because the first characteristic of peace is absence of movements (Evgenjeva 1999). But, it is connected, as well, and maybe even more closely, to the interior state: no more worries. This second aspect may represent the Orthodox Christian cultural context, the word was formed in. Life of a Christian was never easy to live, and meeting the God in paradise was often desired as the only way of liberation from all the sacrifices and difficulties.

As for Italian, the most frequently used equivalent is defunto [past participial from defungere - to die; etymology: from the Latin verb defungi - comp. of de out of and fungi - to accomplish] (De Mauro 2016). A completely different interpretation of death can be noticed, as if it was seen as a mission to accomplish, and life in itself is probably more important than what is expected after it, unlike the content of the Russian term. It seems to be a Latin pagan culture reflection.

In Italian defunto is used, first of all, in formal contexts that presume use of neutral words, a condition perfectly satisfied by euphemisms. 
Another translation of the Russian euphemism is scomparso [disappeared] which is another example of euphemistic metaphorical figurative meaning containing a cultural element relating to the vision of death. This vision refers to the after death processes our body goes through and to the funeral traditions of corpse treatment that literally do not let us see the person again. As a result, death is easily associated with a long absence permitting to create the metaphor.

Buon'anima, the next interpretation of pokojnyj is an expression literally meaning good soul. It is used in order to pay respect and express affection to a dead (De Mauro 2016). The existence and use of such a word combination represent the general attitude of veneration of dead, typical for numerous cultures that often includes saying only good things about decedents. It can be considered a euphemism, as words relating directly to death are omitted, and, with the metaphor a dead person is "transformed" into a good soul that is the result of ameliorating the denotatum.

The following example of interpretation is the word povero [poor] in metaphorical meaning: first of all, a person who does not possess material benefits can be called povero [poor] (De Mauro 2016). A dead does not possess life which is the most precious thing, so the person deserves mercy that is the metaphorical transfer which created euphemistic base of the meaning.

There is another method of translation occurring often enough. It does not have metaphorical nature though. It is the case of omission of the word referring to death. That is another effective technique for euphemisms creation. Instead of the word meaning dead some translators just used names of the persons. In this way they are nearly perceived like living people by the readers.

A completely different tendency of translation is demonstrated by such interpretation as morto [dead]. It is an example of direct nomination deprive of any euphemistic or metaphoric capacities which are characteristic to the Russian term.

\section{Usopshij [Sleeping]}

Another Russian euphemism relating to death is usopshij-sleeping which is now considered an obsolete word, but was of highly common use during the period of Dostoevskij's writing activity. ${ }^{6}$ (Natsional'nyj korpus russkogo jazyka). The employed metaphor reflects, again, the state of quiescence of a dead which in appearance is similar to that of a sleeping person. Therefore, amelioration of denotatum achieved via application of metaphor can be observed which contributes to euphemistic meaning creation. Besides, the concept is strictly related to peace that is typical for the Russian language and already introduced above by the word pokojnyj.

As for the translations into Italian, in some of the versions defunto and morto, analyzed above, were employed.

Another translator preferred to use the word estinto [extinct] which has a Latin root meaning to put something out, relating, first of all, to fire (De Mauro 2016). So, the metaphor contains the reference to identifying life with fire, so something active, colourful, and intense. In this term a vision of death similar to

${ }^{6}$ Natsional'nyj korpus russkogo jazyka [National corpus of the Russian language]. Retrieved from https://ruscorpora.ru 
that of defunto is reflected: life is more important and after there is nothing but a distinguished fire. We can note two contrasting concepts for death: peace, sleeping in Russian, which are more positive, and putting fire out in Italian that represent cultural differences in the vision of life and death.

\section{Othodit' [To Walk Away]}

As for the Russian euphemistic verbs employed to talk about death, one of them is othodit' [to walk away], and its concept makes a reference to the vision of death in the form of a road or a trip. The same verb can be combined with the word train, for example, when it is about to depart. The previously formed meaning of the verb under attention is to finish, to come to an end, first of all, for the contexts of agriculture (Evgenjeva 1999): klubnika otoshla [strawberry walked away] means that strawberry is out of season. Then the metaphorical transfer of meaning towards death can already be traced at that stage.

In the Italian translations the Russian term has a number of interpretations. One of them is rantolare [to wheeze], and here the denotatum of death is substituted with that of the sounds produced by a person who is about to die.

A different metaphoric concept is contained in the option spirare [to exhale] which refers to the last moment of life - the last exhale.

The next interpretation, conceptually, is the closest to the original. The verb andarsene [to go away] lets us imagine walking away, a road and an unknown destination that neutralize the negative emotion generated by the topic. Essere alla fine [to be at the end] is another translation representing a traditional perception of death as the end which is, clearly, not a positive point that reduce the level of amelioration and, as a consequence, of euphemistic veiling. A similar semantic camp is suicide.

\section{Naložit' Na Sebja Ruki [To Put Hands On Oneself]}

The Russian idiom has a figurative meaning of committing suicide. The concept of hand is of use in both Russian and Italian when it comes to expressing physical damage idea. In Russian there is, as well, for example, such expression as podnimat' ruku na kogo-libo [lift a hand on sb] with the meanings to try to beat sb, to beat sb or to try to kill sb, to kill sb (Evgenjeva 1999). The same can be observed Italian: alzare le mani su qc has the identical meaning. In Italian, though, there are no idioms or collocations with the same concept meaning suicide that resulted in problems for translators to interpret naložit' na sebja ruki. As for the euphemistic component, it is conducted via a metaphorical shift, relating to the fact that in most cases violent death or suicide are brought employing hands. In the text the idiom is not referred to a real suicide, but to a moral one of Sonja who became a prostitute to maintain the family of her father. The idiom is used by Raskol'nikov who condemns her choice. The euphemism is used with the function of veiling frightening phenomena that is moral death in this case.

The first examples of translations we analyze are portare la mano su sé stesso, portare la mano su di sé [to put hand on oneself], portare le mani su di sé [to put hands on oneself]. They seem to be cases of loan translation, because the 
expressions are not registered in the dictionaries of the Italian language, nor clear to native speakers.

The second example is alzare la mano contro di sé [lift the hand against oneself], which is probably an attempt to adapt the Italian fixed expression alzare le mani su qc [to lift the hands on sb] which is not used in the context of suicide, making it closer to the original. The Russian word combination, though, the model of translation was apparently taken from, seems to be a different one - podnjat ruku na kogo-libo [lift hand on sb]. And it has a different meaning: to try to beat someone or to beat sb, to try to kill sb or to kill sb (Evgenjeva 1999) and so it cannot be associated with suicide. A similar weak point was found in the idiom mettersi le mani addosso [to put hands on oneself], as neither it can be used when it comes to suicide. In Italian it means to beat $s b$ or to touch, especially in a lustful way (De Mauro 2016). The last interpretation to analyze is suicidarsi [to commit suicide]. Here we deal with a case of direct nomination deprive of any masking, conceptual or cultural elements contained in the original expression.

Taking into consideration the above mentioned characteristics of both Russian and Italian terms used to interpret death, we can conclude that the major part of the interpretations respect the euphemistic and metaphoric nature of the original terms. Besides, some of the Italian translators used words and expressions conceptually similar to those of the Russian text, so some similarities in the perception of death in the cultures can be noticed. As for the differences, the Russian terms tend to endue death with more positive qualities. Apart from the above mentioned conclusions, we can add disregard of some translators for the euphemistic and metaphoric characteristics of the Russian words and expressions that resulted in employing direct terms. And, finally, the problem of loan translation of Russian idioms was observed which results in incomprehensiveness of some terms by readers.

\section{Alcohol Consumption and its Consequences}

Another thematic field resulting in frequent employing of euphemistic means is alcohol, particularly its effect on its consumers which is condemned by Christian and moral principles. Although unlike the previous semantic camp where the generating reason for euphemistic nomination was fear, in this thematic group the reason is masking the consequences of alcohol consumption. So, here we will observe the application of masking euphemisms, taking part of Moskvin's classification (2017: 125).

\section{Hmel'noj [Hopped]}

The most frequent euphemism for drunk is hmel'noj [hopped]. The concept of hop is, first of all, associated with beer, being its main component. In Russian, though, it is used for the consequences of any alcoholic drinks consumption. The veiling results effective, as the concept of the plant created in our mind "protects" our perception from the negative shades contained in the direct terms and the issue itself. 
Some Italian translators preferred to employ the term brillo [an adjective from the verb brillare - to shine] which, as well as the original word, is able to produce a veiling effect, thanks to invoking of the metaphor. The concept used in Italian may be associated with such external signs, as reddish face colour causing "shining" otherwise, if we consider the figurative meaning of "shining," it may be related to provocative or aggressive behavior of a person under effects of alcohol consumption.

Another part of translators, on the contrary, concentrated on the descriptive method of interpretation and decided to apply direct nomination having employed the term ubriaco [drunk] that, obviously, is not able to transfer the euphemistic and metaphorical content of the Russian term.

\section{Hmel' Sidit [Hop Seats]}

One more euphemism containing the concept of hop is hop itself, or hmel' in Russian. This word in its third meaning designates the state of being under the effect of alcoholic substances (Evgenjeva 1999). In the text of the novel Dostoevskij employs the term combined with the verb sidet' [to seat]: hmel' sidit [hop seats]. The verb contributes to the metaphorical, and, as a result, to euphemistic meaning formation that creates an effective masking effect.

In some of the Italian interpretations translators used a different grammatical construction, having substituted the Russian Noun+Verb (to seat) with Verb (to be)+Noun. One of the applied nouns is sbornia [drunkenness] that has uncertain etymology (De Mauro 2016) and is another example of direct nomination which cannot represent metaphorical, euphemistic or cultural elements of the meaning of the Russian term.

Similar lexical units are sbronza [drunkenness] and an adjective sbronzo [drunk]. They have the same meaning and, as well, an uncertain etymology (De Mauro 2016).

Ubriacatura [drunkenness] is one more direct term formed of the reflexive verb ubriacarsi [to become drunk].

As for the verbs employed in creating euphemistic meanings of the semantic camp under consideration, in the original text of the novel we observed using of the verb udarit' [to strike] combined with the word golova [head]. As a result, we have an expression udarit' $v$ golovu [to strike in head] with the meaning to start feeling drunk. Such a concept must come from the perception of alcohol effects like a strike on head that is brusque and coming unexpectedly. In Russian the expression can have both personal and impersonal form. In the text of the novel an impersonal construction is used: udarilo [it stroke], but in Russian there is no any subject, the verb is used in the form of neutral gender which is impersonal, and this characteristic contributes to effectiveness of the euphemistic meaning.

In Italian translations we observe existence of a similar concept to form the euphemistic meaning: some translators used the expression dare alla testa [to give on head] formed thanks to the meaning to strike of the verb. But the verb usually presumes a subject, so, interpreting the Russian text, some translators employed such sentences like il vino gli aveva dato alla testa [the wine had given him on the head], l'alcol gli aveva dato alla testa [the alcohol had given him on the head], 
while in the Russian sentences there is no a subject, and the verb has the form of the neutral genre responsible for impersonal constructions: $v$ golovu udarilo [in head stroke].

A different concept was applied by another translator: salire alla testa [to lift on the head] representing vertical "movement" of the alcohol and its effects inside the body and their arrival to the head. The translator used an impersonal construction, so there was not a direct reference to alcoholic substances that is a favourable condition for the euphemistic element of the meaning.

The last interpretation is fare l'effetto [to do/ to make effect] which is the most neutral thanks to large meaning of the verb fare [to do/to make]. This largeness of the meaning is another good point for creating a euphemism. On the other hand, the word combination is not close enough to the original and does not possess any metaphorical elements in the meaning.

Having analyzed Russian metaphorical euphemisms relating to the semantic camp alcohol and the consequences of its consumption, we can notice that in the Italian translations of the novel there are some differences in the word forming concepts of the terms used by translators. There are, as well, terms having similar both metaphorical and euphemistic elements in the meaning. Finally, the problem of direct nomination for interpretation of euphemistic word and expressions occur.

\section{Mental Abilities}

In the following section we will consider Russian metaphorical euphemisms referring to the field of intellectual abilities and their interpretations into Italian. A frequent use of etiquettical euphemisms will be observed, as they are employed in order not to offend mentioned persons (Moskvin 2017: 118).

A frequent definition for not quite clever characters in the novel is prostovatyj [simple]. It has a very productive suffix in Russian - ova which reduces the grade of a quality expressed by adjective. Such a characteristic creates an additional shadow of veiling to the euphemistic meaning contained in the concept used for the word formation. The concept of simplicity in similar contexts is applied in many languages, including Russian, Italian and English. It refers to the simplicity of thoughts, things discussed by person. Simple instead of stupid makes a great difference, considerably ameliorating the denotatum thanks to the metaphor.

In Italian, as mentioned above, there exists the same concept for stupidity: semplice [simple]. But unlike English, in Italian and in Russian there are diminutive suffixes able to improve the veiling effect. So, in Italian some translators applied sempliciotto [simple (with diminutive suffix otto)] which is a perfectly convenient term to interpret the Russian euphemism.

Another Italian term, quite similar to the previous one, is semplicione [simple (with augmentative suffix one)]. The most important dictionaries of the Italian language, though, that are Grande Dizioinario della lingua italiana by Battaglia (1997) and Il Nuovo Vocabolario di base della lingua italiana di De Mauro (2016) do not contain references to being stupid in the meaning of the word semplicione. It is related more to ingenuous character of a person, while in the dictionary of the 
Russian language the word prostovatyj has the second meaning which is stupid (Evgenjeva 1999).

As for the translations based on the method of direct nomination, there are such examples as stupido [stupid] and assai stupido [very stupid]. If the first term just reveals the real meaning of the euphemized word, the second one even intensifies the direct meaning with the word assai which is quite expressive in Italian. So, these interpretations are not able to accomplish the etiquettical function, typical for the euphemisms of the reffered semantic camp, as they sound offensive.

Another pair of examples, similar to being direct terms, is tardo di mente [late of mind] and limitato di mente [limited of mind]. In the first collocation the semantic nuclear is the word tardo [late]. As the dictionary of Battaglia (1997) reports, this word has the fifth meaning which is referred to low mental and intellectual faculties, and it can be used injuriously. Such a stylistic note proves the euphemistic incapacity of the collocation.

The second word combination contains, as well, revealing and offensive terms that cannot be considered euphemistic.

\section{Conclusion}

The conducted research demonstrates, first of all, that in the original text of F. M. Dostoevskij's novel Crime and punishment, as well as, in its Italian translations, the main semantic camps for metaphorical euphemisms are death, alcohol consumption and its consequences and mental abilities. As for the functional types of metaphorical euphemisms in the novel, the most frequently applied are those used for nomination of frightening phenomena, masking and etiquettical. Besides, we can conclude that metaphor is one of the most effective veiling instruments thanks to its figurativeness which is able to distract well our attention from the real object of communication. Among other effective means for euphemistic veiling, use of diminutive suffixes and omission can be indicated. As for the metaphorical euphemistic concepts in both languages, there are similarities and differences conditioned by those cultural. When it comes to interpretation of such lexical units, they definitely create difficulties for translators, and, as we observed, there are translators who try to resolve the problem, finding appropriate words and expressions to conserve the euphemistic content in Italian, but, there are, as well, those who prefer to employ terms with reduced or absent veiling capacity that are not able to transfer euphemistic and metaphorical elements of the meanings. When metaphorical euphemisms have the form of fixed expressions, the problem of loan translation may occur, leading sometimes to incomprehensiveness of some interpretations formed following this technique. 


\section{References}

Battaglia S (1997) Grande Dizionario della lingua italiana (Great Dictionary of the Italian language), vol. XVIII, vol. XX, Torino: UTET.

Da Silva Correia J (1927) O eufemismo e o disfemismo na língua e na literatura portuguesa (Euphemism and Dysphemism in the Portuguese Language and Literature). Arquivo da Universidade de Lisboa 12: 445-787.

De Mauro T (2016) Il nuovo vocabolario di base della lingua italiana (The new basic vocabulary of the Italian language). Retrieved from https://dizionario.interna zionale.it

De' Paratesi (1969) Le brutte parole. Semantica dell'eufemismo (Bad words. Semantics of euphemism). Arnoldo Mondadori Editore.

Dostoevskij F (2013) Delitto e castigo (Crime and Punishment). Translated by Vittoria Carafa De Gavardo, 5th edn. Roma: Grandi tascabili economici Newton Narrativa.

Dostoevskij F (2018) Delitto e castigo (Crime and Punishment). Translated by Damiano Rebecchini, 7th edn. Milano: Giangiacomo Feltrinelli Editore.

Dostoevskij F (1959) Delitto e castigo (Crime and Punishment). Translated by Eridano Bazzarelli. Milano: Ugo Mursia\&C.

Dostoevskij F (1981) Delitto e castigo (Crime and Punishment). Translated by Alfredo Polledro (1930); Introduction by Leonid Grossman. Torino: Einaudi, Collana: gli struzzi.

Dostoevskij F (1907) Delitto e castigo (Crime and Punishment). Milano: Società Ed. Milanese.

Dostoevskij F (2015) Delitto e castigo (Crime and Punishment). Serena Prina (ed). Milano: Mondadori Libri S.p.A.

Dostoevskij F (2019) Delitto e castigo (Crime and Punishment). Translated by Giorgio Kraiski. Milano: Garzanti XXVII edizione.

Dostoevskij F (2017) Prestuplenije i nakazanije (Crime and Punishment). Moskva: Izdatel'stvo "E".

Evgenjeva A (1999) Slovar' russkogo jazyka (Dictionary of the Russian Language), vol. 4-h t. RAN, Institut lingvisticheskih issledovanij: 4-e izd., ster. Moskva: Rus.jaz.; Poligrafresursy.

Holder R (2002) How not to say what you mean. A dictionary of euphemisms. Oxford University Press.

Katsev A (1987) Evfemizmy-neologismy v anglijskom jazyke (Evphemisms-neologisms in the English language). Leksicheskaja semantica $i$ fraseologia: sbornik statej, pp. 64-74. Leningrad.

Katsev A (1988) Jazykovoje tabu i evfemija (Language taboo and euphemia). Leningrad.

Kröll H (1984) O Eufemismo e o disfemismo no português moderno (The euphemism and dysphemism in modern Portuguese). Biblioteca breve, volume 84. Instituto de cultura e língua portuguesa. Lisboa: Ministério da educaçao.

Moskvin V (2017) Evfemizmy v leksicheskoj sisteme russkogo jazyka (Euphemisms in the lexical system of the Russian language). Moskva: LENAND.

Natsional'nyj korpus russkogo jazyka (National cosrpus of the Russian language) http://ruscorpora.ru

Rawson H (1981) A dictionary of euphemisms\&other doubletalk. New York: Crown Publishers, Inc.

Seničkina E (2008) Slovar' evfemizmov russkogo jazyka (Dictionary of euphemisms of the Russian language). Moskva: Flinta. Nauka.

Wardhaugh R (2006) An introduction to sociolinguistics, 5th edn. Blackwell Publishing. 



\title{
Power and Resistance: Disappointment of Socialism in Howard Brenton's Magnificence
}

\author{
By Ramin Farhadi \& Mohammad Amin Mozaheb
}

\begin{abstract}
The Events of May 1968 influenced the stage of the British playwright Howard Brenton substantially. He paid much attention to the aftermaths of May 1968 in his plays to revision the strengths and pitfalls of the Events. In his play Magnificence (1973), he stages contemporary British social history under the influence of May 1968 along with the terrorist attack against then British Minister of Employment, Robert Carr, by representing a group of young socialists squatting empty houses and exchanging their socialist and idealistic ideas with one another. This study, therefore, aims to explore the way in which Brenton's drama revisions the defeat of the socialist ideals of May 1968 Events by dramatizing lack of harmony and conflicting opinions regarding the modes of public resistance among the dissenters. The study also articulates that Brenton's historical drama grants him a license to make use of the recent past, May 1968 and also embodied as Lenin appeared in the middle of the play, to evaluate the present and express strong disapproval of the British conservatism which has completely silenced any dissident voice in the British society. The study applies Foucauldian notions of power and discourse, as well as close reading of the play to fulfill the research objectives.
\end{abstract}

Keywords: Historical drama, Howard Brenton, May 1968, Michel Foucault, Socialism

\section{Introduction}

After the Second World War, there was a renewal of interest in writing history plays among the British playwrights. This twentieth century historical playwriting, as Harben (1988: 1-2) observes, which is to some extent in affinity with the popular Elizabethan and Jacobean historical theatre, attempts to stage the past in order to re-evaluate and re-interpret it. What the postwar playwrights have tried to achieve is the argument that there is no settled truth in history. History and the writing of it are hence subjective realms in which there are multiple interpretations that can be offered for a single event of past.

Howard Brenton's theatrical career which began in the mid-1960s was under great influence of the civil unrest of May 1968 in France. At that time, he was present in Paris, and thus gained a first-hand experience of the mass strikes and the confrontation between the French police force and the protesters. One of the important outcomes of May 1968 was the emergence of new social movements which was discussed in detail by Buechler (1999) and Scott (1990) in their monographs. Playwrights then were able to stage sensitive and controversial issues of their day, and to question the conventional assumptions of their societies which potentially were ideological. In this regard, Brenton formed serious attacks on the British right-wing policies by practicing a socialist theater. Zeifman (1993: 132) holds that Brenton challenges those policies by demythologizing the historical

${ }^{*}$ M.A. in English Literature, Azad University of Karaj, Iran.

${ }^{\dagger}$ Assistant Professor, Language Center, Imam Sadiq University, Tehran, Iran. 
figures and events alongside of his socialist thinking on his stage. Freshwater (2009: 89) notes that Brenton has a predilection for dramatization of uncomfortable situations and "painful confrontations with previously unsuspected truths." A case in point is the encounter of Lenin, a historical figure, with the young leftist squatters in Magnificence, the play by which Brenton gained considerable attention in 1973.

Magnificence represents a post-1968 English society where a group of socialist dissenters desperately struggle against the existing injustices of their society. Boon (1991: 77) states that Magnificence is "concerned with the aftermath of the èvènements" of May 1968, though it is written five years later. In his other study, Boon (2015) mentions Brenton's use of social-political experience to develop his socialist stage. Brenton shows in Magnificence, as it is typical of his other 1970s plays, a staging of the past and the present at the same time to use both against one another (Pennino 2018). Rabey (2003: 109), moreover, maintains that the play's main concern is twofold: the opposition between socialism and English fascism represented by a revolutionary Jed and a Tory MP, and an evaluation of "revolutionary impulses". Magnificence is a piece that Brenton re-evaluates and re-thinks what went wrong in May 1968 and how the suppression of the authorities affected deeply his generation; thus, in an essay written in 1975 he expressed his idea on May 1968 and the emergence of radical playwrights as follows:

"May 1968 was crucial. It was a great watershed and directly affected me. A lot of the ideas in Magnificence came straight out of the writing of that time in Paris, and the idea of official life being like a screen...May 68 disinherited my generation in two ways. First it destroyed any remaining affection for official culture. The situationists showed how all of them, the dead greats, are corpses on our backs Goethe, Beethoven - how gigantic the fraud is. But it also, secondly, destroyed the notions of personal freedom, anarchist political action. And it failed. It was defeated. A generation dreaming of a beautiful utopia was kicked - kicked awake and not dead. I've got to believe not kicked dead. May 68 gave me a desperation I still have." (Brenton 1989: 20)

Taken as a whole, this study, in the three sections below, articulates that Brenton's Magnificence serves multiple political purposes including re-evaluation of the socialist principles in the British society in the aftermath of May 1968 and the reasons that a transformation based on leftism never occurred in the 1970s. By using Foucauldian concepts of power and discourse, as well as character analysis, it next investigates Brenton's representation of power relations to cite as the main reason of the leftists' disappointment in the realm of politics in the 1970s UK. Finally, the study explores that terrorism or any form of violent resistance is rejected by Brenton as the hindrance to the effectuality of socialist belief in the political arena. 


\section{Discussion}

\section{Economic Inequality and Disharmony of Resistant Strategies}

Before exploring the play critically, it seems essential to briefly mention the social and political context of Britain in the early 1970s. At the time of Brenton's composing of Magnificence, Britain was experiencing grave rapid changes in social, economic and political realms. Sensitive issues like the Campaign for Nuclear Disarmament started afresh; political activities of British young counterculture were critical in their continuity; a clash between British soldiers and civil rights strikers in 1972 in Northern Ireland resulted in thirteen casualties - referred to as the Bloody Sunday - are striking cases in point (Rabey 2003: 109-110). As Burns (2009: 222) mentions, in the late 1960s and the early 1970s sexual minorities and feminist movements strengthened along with a resurgence of Irish nationalism.

Apart from these issues, nation's economic problem was a source of inspiration for Brenton to compose his play. In this respect, Britain's first urban guerrilla group, Angry Brigade's attack on the house of then Government Minister of Employment Robert Carr in 1971 was the incident that Brenton dramatized in his play to question violent mode of resistance by the radical leftists. It is chiefly for this reason that the words like "empty houses" and "terrorism" are repeated throughout Magnificence. Along with staging this contemporary historical event, as has been stated, the civil unrest of May 1968 was another policy that Brenton adopted in his play to explore the reasons of the failure of a left-wing revolution in the UK. In addition to this, the corruption of a politician and the brutality of police were other concerns for Brenton to dramatize.

Magnificence involves two plots. In the first plot, there is a group of young squatters - Jed, Cliff, Will, Veronica, and Mary - that illegally occupy the empty houses in London. They all belong to the middle classes, and they are socialist dissenters. Brenton stages their ongoing struggle not only with the authorities, but also with one another. As soon as they squat a derelict house, they start to reveal their conflicting opinions about how they should oppose political corruption of the authorities. The second plot begins when the police attack the squatters and Jed is imprisoned as a consequence. In this plot, two corrupt and homosexual politicians - Babs and Alice - are presented, and between the two the latter becomes a target for Jed's revenge at the end.

From the outset, the image of the house is significant in the text. Empty houses presented in the play denote the difficult economic conditions of England in the 1970s when many individuals of middle and lower classes were homeless, as Will explicitly mentions: "Look at this place. Empty. And how many other places, good houses, all over the city...Empty" (Brenton 1989: 42). Yet the image of house has another importance, and this is it can nurture the imaginative and idealist thinking of the squatters. It can provide them an opportunity to "spray slogans and hang banners" in the house, not streets (Boon 1991: 77). As a group of socialist dissidents, they are on a collision course, and lack harmony. To use Gaventa (1980: 6), "decision-making" and acting as a unified group indicate 
people's interests, and it is evident that the young socialists simply lack this. Cliff is critical of Jed's aggressive actions; Veronica is hesitant about their role in public, and Will is irritable and aggressive, especially toward Jed. The manner of their squatting is a case in point. After an unsuccessful fiddling with the door, Will seeks to "bash it down" (Brenton 1989: 36) which is in contrast with by Jed's peaceful suggestion of entering silently. Will's violent tendency will be displayed more openly later in the play.

In the beginning of the play, the presence of disciplinary power can be seen. Foucault (1977: 89) maintains that from the French Revolution onward, power mechanism has profoundly changed, and the disciplinary or bourgeois form of it emerged. This form of power, as Foucault continues, is at odds with monarchy or royal power which exercises from top to bottom; instead, it operates from the bottom to the top (1980: 94). Of the main features of this form of power is the use of disciplinary means of punishment including surveillance, monitoring, prison and the discourse of law. The essential function of discipline is to reduce the encounter of power with its subjects; thus, an indirect exercise of the power over the subjects can be practiced (Foucault 1977: 215). It is based on this characteristic that the neighbors inform the police about the presence of the squatters in the play, and the group's protest inside the walls, not on the streets.

As they enter the house, their lack of harmony reveals itself. In fighting against power discourse they do not have a clear and collective resistance strategy. On the other hand, power uses many discourses to be exercised in a society. According to Lotringer (1996: 224), these discourses not only produce power, but also make it more stable and integrated; hence, resistance should have the same operational effectiveness as power does. As an illustration, Mary has prepared a banner to hang out the window which is questioned by Veronica who prefers to write slogans on the inside walls:

"Veronica: What are we going to do with it?

Mary: Ang it out the window.

Veronica: For all the World to see?

Mary: That's the idea." (Brenton 1989: 39)

In order to understand Brenton's representation of characters' difference of opinion and their disharmony, it is useful to classify them into three groups: 1) Jed and Cliff, 2) Will and Veronica, and 3) Mary. Firstly, Jed and Cliff have taken the responsibility of everyone's safety and of maintaining their secrecy. In this respect, Cliff barricades the door inside, then he observes the street activities from the mere window opening outside when Jed asks "Barricade the front door, eh Cliff?" (Brenton 1989: 39). They are "virtually silent" and are "the characters with the least to say" (Boon 1991: 39). Quite opposite, Will and Veronica are energetic, talkative and are likely to be effective in the situation.

The second character classification is Will and Veronica that mostly dominated the first scene of the play. To begin with, Will is the only one whose attitude toward resistance to the British government tends to be aggressive and violent: he is an exact stage adaptation of an outrageous protester of May 1968. In the opening scene he forcefully takes the paint spray from Veronica so as to write 
"ANARCHY FARM" on the inside wall (Brenton 1989: 38). In other words, he is an anarchist and a fighter who later in the play will be the first one to physically attack the bailiff, Mr. Slaughter, and his constables to not be evicted from their squatness. At the moment of the bailiff's attack to evict the squatters, Will laying his ear on the ground requests "please, Mr Bailiff. Make the blood flow," and to Veronica he says "Pricks and kicks I can understand" (Brenton 1989: 46). His mode of resistance, as it seems patently obvious, is a physical and violent confrontation with the law enforcement. On the contrary, Veronica is regarded as a newcomer and a stranger to the group. In her current political activity, she is in two minds about staying or leaving the group. She most of the time drowns herself in a verbal debate with other members of the group to be somewhat in charge and be superior. Although she encourages others to stand still and adopt an effective strategy of resistance, she, at the same time, questions the ulterior motive of the group's political activism: "...we social activists...we're just a passing phenomenon, which leaves fag butts on the floor" (Brenton 1989: 60). Therefore, this pair mostly seeks to be superior one physically and the other verbally.

Finally, apart from any other members of the groups is Jed's pregnant partner, Mary. She usually sits or stands on the center of the stage, and silently watches others' activities. As mentioned above, her mode of resistance is to engage the public with themselves; for instance, her hanging of a banner out the window. She is almost ignored by others; they take no notice of Mary's definition of political protest (her banner hanging). Similarly, in the second half of the play, Jed rejects her to not take his vengeance on Alice. Briefly speaking, Boon holds that, despite the fact that as a dissident group they are energetic and self-indulgent, they write slogans and hang banner inside the house, indicating their inward-looking and hesitancy towards "magnificent" political gesture (Boon 1986: 215).

At the same time, the exercise of power cannot be ignored completely, with regard to the squatters' inward-looking and political resistance inside the house. It seems that fear of being confronted and suppressed by disciplinary power can be one of the reasons of their squatting. In this respect, Deleuze (1989: 26) holds that modern societies can be interpreted as disciplinarian, and power relations are exercised merely by powerful forces in the society, which would result in creating an authoritarian society. There is constant observation made by the disciplinary power, which provokes the group's fear of being in view; in effect, Veronica's desperate statements loudly announce the similarity between a person and a fox, and a world that is suddenly deprived of vivacious lives on the surface:

"Homeless in the city. And where are they? Why aren't there tents all over the Hyde Park? Human foxholes in Kensington Gardens? But the people are there poked in somewhere. Like to hide litter, ramming it into the cracks in the walls. Ramming people, into cracks in the walls." (Brenton 1989: 42)

Veronica, here, refers to the futility of Will's writing slogans on the wall. The people, in her view, are not really present in public. She virtually declares to the audience that "don't let write messages and slogans" (Brenton 1989: 42) because for her opposition should be aroused with reference to the issue of "homelessness" (Boon 1986: 215). 
To draw a conclusion, Brenton first represents Will's anger toward British society and its authorities. He, then, puts Veronica's ideas forward. Owing to the fact that she is a newcomer, she mentions both the futility of the group's initial acts, the occupation of the house, writing slogans, and hanging banners in the house for the future generation to understand them. In other words, she is doubtful about the group's political aims. As Sheridan (1980: 183) notes, just as power contains plurality of modes and discourse, resistance ought to be as such; in this connection, each squatter adopts a different aim and mode of resistance, which not only organizes them as a group of political dissidents, but also, at the same time, hinders their efforts to constitute a cohesive group.

\section{The Modern Forms of Disciplinary Power: Law Enforcement}

Two law enforcement agents, Mr. Slaughter and Constable, appear on the stage to evacuate the squatters from their place. These two authority figures belong to the discourse of law. What is significant here is Slaughter's language and attitude toward the squatters as well as the meaning of his name which is killing people or animals in a wide scale. As agents of power, they regard the squatters as disruptive and "inefficient behavior" (Gaventa 1980: 7). Brenton shows that how the discourse of law should be defined and implemented throughout the society, and how individuals are understood by the existing laws. Here, the image of the police in public's eye is also another Brenton's concern. There can be seen here a direct tie between the use of language and laws. Fletcher (2003: 85) writes that the discourse of law can justify carrying out violent acts and encounters. Hence, Slaughter assures Constable:

"The Bailiff charter, mate. (Fiercely) I am going to pull this off. One last stroke. Ousting our friends up there. I am going to bust that lot, cleanly, utterly. A matter of wounded pride...Don't worry I'm a professional. A good dustman. Just pick up the bin up, and bang." (Brenton 1989: 58)

The primary objective of law is to provide and secure the social orders. Foucault points out that, from the Middle Ages to the present era, the exercise of power in the Western societies is by the discourse of law (1978: 87). He adds that the essential function of law is to legitimatize sovereignty and authority; in other words, law has to make impact on individuals to maintain the order of the ruling class. Slaughter and Constable are authorized to forcibly evict young socialists. Before their attack, the group realizes that there will be war against them, so they begin singing: "Warlords, corrupt officials, local tyrants, evil gentry. They are blind and all is dark before them" (Brenton 1989: 50). The reaction of police Constable to their singing is interesting; he tells Slaughter that they are "like a churchload of old women, singing, All Things Bright and Beautiful" (Brenton 1989: 50), which in a sense undermines them.

Brenton's first-hand experience of May 1968 in Paris provoked him to stage Slaughter's wave of violence against the squatters. The law enforcement's exertion of violence is to marinating domination and order for the benefit of the lawmakers 
and authorities; it is also a way of concealing the existing injustices and silencing the dissident voices (Foucault 1978: 88). As follows, from the exchange between Slaughter and Constable about their jobs, audiences understand that all of their previous evictions were done by violence and physical force: "I've got murder in my heart...That's a way of putting it. Murder..." (Brenton 1989: 58). In the end, in Jed's words, "the Bailiff and his boys" in no time attack the squatters (Brenton 1989: 70).

The clash between the agents of law enforcement and the squatters ends in disaster. The fight between Will and Slaughter eventually leads to Mary's loss of her child. The group is dispersed and Jed is sent to prison for a period of nine months. Yet during the clash between the police and the group, Veronica's burst of desperate expressions is significant; she draws the audience's attention to futility of their political activity and aim:

"(Near tears). Liberation City? (She draws back the tears.) I loathe us. I loathe all the talks we had. That we'd really do it. Come down to the people whom it really hits...I loathe our stupid, puerile view of the world...I loathe what we've descended to here...ten days with fleas and the tin opener lost, never for once questioning...in any way...for us it's come down to sitting on a stinky lavatory for ten days...'Mobilize the people?' We can't mobilize a tin opener..." (Brenton 1989: 65-66)

What Brenton dramatizes in Magnificence, regarding the first half of the play, is to arrive at this conclusion that the current modes or strategies of resistance after the events of May 1968 are of no potential effectiveness in the present British context. One compelling reason is, as Gaventa puts it, "the sense of powerlessness" experienced by the British young socialists (Gaventa 1980: 17), due to their continual defeat and suppression which made them entirely ineffective in adopting a coherent resistant strategy.

\section{Petrol Bomb: Terrorism against the Power Agents}

After serving his prison term, Jed's attitude and his political position changed sharply. The second half of the play is about Jed's revenge. From a peaceful dissident, he transforms into a revolutionary hardliner. His obsession with revenge separates him from Mary and other characters in the play like Cliff and Will. Jed's characterization closely resembles him to a revolutionary street protester of May 1968 in Paris (Rabey 2003: 109). As a comparison, Will has changed into a "drug-raddled parody of his early idealistic self" (Boon 1991: 77); at this time, all his idealism is at an end. Jed forcefully attempts to accompany Will in this radicalism. Will resentfully asks Jed: "What were you trying to do? Elevate the whole of Brixton Goal? Turn it upside down? Shake all the nasty creepy crawlies out?...Sorry...I felt moved....at seeing you again" (Brenton 1989: 86). The radicalism of Jed is rejected by both Cliff and Will. Even in the fifth scene, Brenton represents Lenin to persuade Jed not to pursue his evil plan of terrorism, and yet Lenin's leftism is rejected by Jed's radicalism (Brenton 1989: 85 ). Brenton by representing Jed's radical transformation puts the radicalism and violent resistance seriously into question. Brenton is also critical of the British 
ruling class and power authorities that have silenced the dissenters and suppressed any dissident politics that is inconformity with their ideological stances. As Bull (1984: 50) observes, Brenton's play is a rejection of radicalism and terrorism as well as celebrating a lost idealism promoted by May 1968 socialist protesters.

What is apparent, prison increases his anger and obsession with vengeance. The function of prison is also questioned in the text. Prison, here, is ineffective in a way that a lawbreaker transforms into a revolutionary terrorist whose obsession is to assassinate a corrupt Cabinet minister - Alice. The image of prison in the play has not properly functioned as a deterrent and modifier in Jed's behavior. It obviously nurtured his terrorism which eventually leads him to his tragic destiny at the end of the play (Boon 1991: 79). Here, Foucault explains how an effective prison system might create radicalism in a prisoner's attitude:

[...] this was organised around the prison system, and the bourgeoisie erected an ideological barrier around those who went to prison or who had been in prison (an ideology about crime, criminals, theft, the mob, degenerates, "animals") which was in part linked with racialism. (1980: 17)

After his release, Jed forces Will to accompany him for his vengeance. The previous violent behavior of Will is now affecting Jed, and because of that Will calls him "Speedy Gonzales" (Brenton 1989: 86). Speedy Gonzales is an animated mouse character whose high speed and dexterity enables him to deal with complex situations. This is how Will refers to Jed's radical extremism. Moreover, in order to force Will to join him, Jed presses Will's wrist hard and puts off his shirt as a practice to seizure of Alice in the last Scene. Here, Jed exercises power over Will to control his body physically; this is the very basic definition of power: to have control over a subject (Foucault 1977: 57).

The two political figures in the play are Babs and Alice represented as corrupt politicians by Brenton. Babs attempts to transfer power to his younger counterpart, Alice, in the fourth scene. This power transference is the process of creating a new direction in the British politics which, in Boon's view, a Tory as Babs is going to be supplanted "by the new English Fascist" - whose embodiment is Alice (Boon 1991: 87). Brenton represents this new form of politics, the English Fascism, in his other plays as well; a case in point is The Churchill Play (1974) in which the late British Prime Minister Winston Churchill is responsible for the formation of a highly Fascist society that marked the end of individual liberty and freedom of expression. The young Alice is the new public face of the ruling class, and since he is related to housing program, he becomes Jed's target for revenge.

Ultimately, Jed seizes Alice in his garden as calling him "Mr Public Man" (Brenton 1989: 100). After handcuffing him, Jed puts a mask with a gelignite bomb over Alice's head. Jed equips himself with a bomb to take revenge. This is due to the fact that he wants to remove Alice completely-not only physically, but also publically. He would like to strike fear by a blast, so he uses a gelignite bomb to destroy the smiley face on the TV (Boon 1991: 78). As Brenton points out in an interview, in May 1968 one of the utterly devastating consequences of bombing is to observe blood-spattered streets with no individual care to collect the severed 
bodies (Hayman 1976: 57). As a result, Jed tries to destroy a media image which is an ideological means of power.

Jed and Alice's struggle is also significant in a sense that both sides attempt to empower one another. Alice by his art of speech and manipulation confidently tries to stop Jed's from his action. Yet the bomb accidently goes off and both die instantly. At the end of play, Jed's revolutionary terrorism is rejected and rebuked by Cliff, a character who is mostly silent throughout the play and speaks the final words for Jed:

"Jed. The waste. I can't forgive you that.

A pause.

The waste of your anger. Not the murder, murder is common enough. Not the violence, violence is everyday. What I can't forgive you Jed, my dear, dead friend, is the waste." (Brenton 1989: 106)

In sum, Breton in Magnificence stages the revolutionary socialism of the young generation after the events of May 1968 and, as Patterson (2003: 95) states, his commitment to this kind of theatrical practice. Brenton by using contemporary historical material represents two antithetical discourses of dissidence and power. He blames a group of young socialists for their lack of harmony and agreement in having common political aims, particularly Jed whose act of terrorism somehow marks the failure of socialism in being effective in the British context (Boon 1986, 1991). He also attacks the authorities in power, particularly the corrupt politicians that have silenced any dissident voices in Britain (Rabey 2003). Magnificence is a drama of longing for a unity in having the right, effective mode of resistance to power when, for the young generation of the British, the right-wing policy was no longer considered effective.

\section{Conclusion}

The student uprising in Paris in 1968, known as the Events of May, had major impacts on the British theatre, specifically the stage of the prominent playwright Howard Brenton. It, moreover, inspired Brenton to historicize this stage to treat with historical awareness of his society, to launch attacks against the power institutions, and to express approval of socialism. In his socialist-historical drama Magnificence (1973), apart from his criticism of the British conservatism, he also questions the left-wing policy of public resistance of his contemporaries. In his play, by staging a group of young socialist squatters occupying illegally the empty houses of London, Brenton criticizes housing policy and the unpleasant economic condition of British society in the early 1970s. Side by side with the squatters, Brenton stages the law enforcement, Mr. Slaughter and the Constable, as well to show the bitter confrontation of the British government with any voices of dissent.

The play is divided into two halves: the first deals with oppressive and physical aspects of power such as the police force and the second mainly focuses on Jed's revenge and the smiling face of power in the media, embodied as the corrupt MP Alice, is bitterly critical of the disciplinary forms of power theorized 
by Michel Foucault in the 1970s - forms such as surveillance and prison. Accordingly, in order to achieve effective modes of resistance, Brenton puts some into trial, from writing slogans and hanging banner, i.e., the peaceful ways of opposition, to more radical and pragmatic approach like Jed's petrol bomb attack at the close of the play. The playwright condemns Jed's terrorism, his violent form of protest, and associates it with one of the abject failures of the socialist movements of the late 1960s and early 1970s. Overall speaking, Magnificence shows that lack of harmony and effective decision-making among the socialists, as well as the suppression and application of force by power mechanisms such as the police might be the main causes of the failure of the leftist movements in the UK.

\section{References}

Boon R (1986) Howard Brenton: A Critical Study of the Plays. Unpublished doctoral dissertation, University of Sheffield, Sheffield.

Boon R (1991) Brenton: The Playwright. London: Methuen.

Boon R (2015) About Hare: The Playwright and the Work. London: Faber \& Faber.

Brenton H (1989) Plays One. London: Methuen.

Buechler SM (1999) Social Movements in Advanced Capitalism. Oxford: Oxford University Press.

Bull J (1984) New British Political Dramatists. London: Macmillan.

Burns WE (2009) A Brief History of Great Britain. New York, NY: Facts on File.

Deleuze G (1989) Foucault. Translated by S Hand. Minneapolis: University of Minnesota Press.

Fletcher G (2003) Law. In John Searle, B. Smith (Eds.), pp. 85-101. Cambridge: Cambridge University Press.

Foucault M (1977) Discipline and Punish: The Birth of the Prison. Translated by A Sheridan. London: Allen Lane.

Foucault M (1978) History of Sexuality Volume one: An Introduction. Translated by R Hurley. New York, NY: Pantheon Books.

Foucault M (1980) Power/Knowledge: Selected Interviews and Other Writings 19721977. C Gordon (Edn.). Translated by C Gordon, L Marshal, J Nepham, K Soper. New York, NY: Pantheon Books.

Freshwater H (2009) Theatre Censorship in Britain: Silencing, Censure and Suppression. Basingstoke: Macmillan.

Gaventa J (1980) Power and Powerlessness: Quiescence and Rebellion in an Appalachian Valley. Oxford: Clarendon.

Harben N (1988) Twentieth-Century English History Plays: from Shaw to Bond. London: Macmillan.

Hayman R (1976) British Theatre Since 1955: A Reassessment. Oxford: Oxford University Press.

Lotringer S (Ed.) (1996) Foucault Live: Collected Interviews, 1961-1984. New York, NY: Semiotext(e).

Patterson M (2003) Strategies of Political Theatre: Post-War British Playwrights. Cambridge: Cambridge University Press.

Pennino A (2018) Staging the Past in the Age of Thatcher. Basingstoke: Macmillan.

Rabey DI (2003) English Drama since 1940. London: Pearson Education.

Scott A (1990) Ideology and the New Social Movements. London: Unwin Hyman. 
Sheridan A (1980) Michel Foucault: The Will to Truth. London: Routledge.

Zeifman H (1993) Making History: The Plays of Howard Brenton. In J Acheson (Eds.), British and Irish Drama Since 1960, pp. 130-145. New York, NY: St. Martin's Press. 
